\title{
CANAdA's AgING OIL AND GAS INFRASTRUCTURE: WHO WILL PAY? The Public and Private Cost Recovery Frameworks
}

\author{
Michael A. Marion, Michael G. Massicotte \\ AND JESSICA L. DUHN*
}

This article examines the legal and practical issues surrounding the costs of reclaiming, remediating, and abandoning Canada's aging pipelines, wells, and other oil and gas facilities as they reach their functional end of life. The authors address the recovery and distribution of these costs from two perspectives: the public regulatory and legislative frameworks in place in the key oil and gas producing regions of Canada; and the statutory, contractual, and common law framework through which private industry participants share or limit their liability.
Cet article examine les questions juridiques et pratiques relatives au coût de la bonification, de la remédiation et de l'abandon de pipelines vieillissants au Canada ainsi que des puits et autres installations pétrolières et gazières arrivant en fin de vie. L'auteur aborde le recouvrement et la distribution de ce coût de deux points de vue, notamment du point de vue de la réglementation publique et législative existante dans les régions productrices de pétrole et de gaz naturel au Canada, et du point de vue statutaire, contractuel et de la common law permettant aux participants de l'industrie de partager ou de limiter leur responsabilité.

\section{TABLE OF ConTENTS}

I. INTRODUCTION . . . . . . . . . . . . . . . . . . . . . . . . . . . . . . . 331

II. The Public Cost Recovery Framework $\ldots \ldots \ldots \ldots \ldots \ldots \ldots 32$

A. The Alberta Statutory and Regulatory FramewORK . . . . 332

B. THE FEDERAL STATUTORY AND REgULATORY FRAMEWORK . . . . 337

C. COMPARATIVE FRAMEWORK OF CANADA'S KEY

OIL AND GAS PRODUCING REgIONS . . . . . . . . . . . . . . . . 340

D. INSOLVENCY AND ORPHAN FUNDS $\ldots \ldots \ldots \ldots \ldots$. . . . . . . . . 342

III. The Private Cost REcovery Framework . . . . . . . . . . . . . . . . . 344

A. THE THRESHOLD OWNERSHIP ISSUE . . . . . . . . . . . . 345

B. SHARING of Costs AMONG CURRENT OWNERS . . . . . . . . . . . . 346

C. Private Recovery Against Former Owners . . . . . . . . . . . . 352

D. Contractual Allocation or ExClusion of Liability . . . . 362

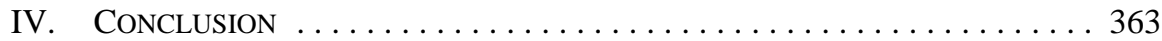

\section{INTRODUCTION}

A significant portion of Canada's oil and gas infrastructure is fast approaching its functional end of life. ${ }^{1}$ For example, in Alberta, approximately 30 percent of pipelines are

Michael A Marion and Michael G Massicotte are partners and Jessica L Duhn is an associate at the Calgary office of Borden Ladner Gervais LLP.

Alberta's oil and gas infrastructure has been the focus of a number of recent government-initiated reports, which contain various statements regarding Alberta's aging infrastructure including, in particular, upstream facilities and gathering systems. See e.g. Group 10 Engineering, Alberta Pipeline Safety Review, December 7, 2012; Energy Resources Conservation Board, Alberta Pipeline Safety Review: ERCB Response to the Minister of Energy (Calgary: Energy Resources Conservation Board, 2013); Alberta Energy Regulator, Report 2013-B: Pipeline Performance in Alberta, 1990-2012 (Calgary: Alberta Energy Regulator, 2013) [AER Report]. 
greater than 25 years old and 5 percent are greater than 50 years old. ${ }^{2}$ As infrastructure continues to age, there will be an increased need to reclaim, remediate, and abandon pipelines, wells, and other oil and gas facilities, and corresponding costs to do so (Environmental Costs). As the frequency of these activities and their associated costs continue to increase and more frequently become the subject of regulatory enforcement and civil disputes, significant and complex legal and practical issues will emerge.

This article will address the recovery framework for Environmental Costs from two key perspectives. First, it will provide a summary of the federal and provincial or regional legislative and regulatory frameworks in the key oil and gas producing regions in Canada ${ }^{3}$ which govern the public control over, liability for, and priority over Environmental Costs. ${ }^{4}$ Second, it will provide an overview of the Canadian statutory, contractual, and common law framework through which private industry participants may attempt to share in or limit their liability for Environmental Costs.

\section{The Public Cost Recovery Framework}

\section{A. The Alberta Statutory AND REgUlatory FrameWORK}

1. The Alberta Energy Regulator AND

THE RESPONSIBLE ENERGY DEVELOPMENT ACT

On 17 June 2013, the Responsible Energy Development $A c t^{5}$ was proclaimed in force, save and except for certain specified sections. Under REDA, the Alberta Energy Regulator (the AER or Regulator) has become Alberta's single regulator of energy developments falling within provincial boundaries, including more than half of Alberta's pipelines, amounting to approximately 400,000 kilometres.

AER Report, ibid at 11.

For the purposes of this article, the "key oil and gas producing regions in Canada" are the western provinces of British Columbia, Alberta, Saskatchewan, and Manitoba, and the northern territories of the Northwest Territories and Nunavut. The article was limited in scope in this manner having regard to the geographical location of the majority of the operations of the participants at the 2014 CELF Jasper Seminar, where this article was presented, and in light of 93 percent of Canada's production of crude oil and equivalent in 2013 being derived from the western provinces of British Columbia, Alberta, Saskatchewan, and Manitoba: see National Energy Board, Estimated Production of Canadian Crude Oil and Equivalent, online: National Energy Board <www.neb-one.gc.ca/clf-nsi/rnrgynfmtn/sttstc/crd lndptrlmprdct/stmtdprdctn-eng.html>.

$4 \quad$ There are a number of provisions under the Pipeline Act, the Oil and Gas Conservation Act, and the Oil Sands Conservation Act which provide the Alberta Energy Regulator with various enforcement and compliance mechanisms potentially applicable in the context of aging infrastructure, but which do not address the issue of who is liable to pay the ensuing costs of addressing the consequences of the aging infrastructure: see e.g. Pipeline Act, RSA 2000, c P-15, s 35 (reporting obligations); Oil and Gas Conservation Act, RSA 2000, c O-6, s 7 [OGCA] and Oil Sands Conservation Act, RSA 2000, c O-7, s 6 [OSCA] (broad authority to make any just and reasonable orders); Pipeline Act, ibid, s 29, OGCA, ibid, s 44 and OSCA, ibid, s 9 (suspension of construction or operation of a pipeline where contravention of the Pipeline Act or direction of the Regulator, or improper, hazardous, inadequate or defective method, practice or equipment); Pipeline Act, ibid, s 51 and OGCA, ibid, s 106 (suspension of operations, refusal to consider application, or requirement of abandonment and reclamation deposits prior to granting licence, where non-compliance with an order or outstanding debt); OSCA, ibid, s 15 (cancellation or suspension of approval where similar non-compliance). See also Pipeline Act, ibid, s 54(1), OGCA, ibid, s 110(1) and OSCA, ibid, s 26(1) (fines for enumerated offences); Alberta Energy Regulator, Directive 019: Compliance Assurance (Calgary: Alberta Energy Regulator, 2010). SA 2012, c R-17.3 [REDA]. 
The implementation of this single Regulator took place in three phases. Under the first phase, which occurred on 17 June 2013, the AER only assumed the energy development regulatory functions formerly administered by the Energy Resources Conservation Board (ERCB). Under the second phase, which occurred on 30 November 2013, the AER further assumed the regulatory functions and responsibilities: (1) for which Alberta Energy was previously responsible under Part 8 of the Mines and Minerals Act; ${ }^{6}$ and (2) of Alberta Environment and Sustainable Resource Development (ESRD) under the Public Lands Act. ${ }^{7}$ The third phase involved the AER's assumption, as of 29 March $2014^{8}$ of regulatory functions and responsibilities from ESRD under: (1) the Environmental Protection and Enhancement Act; ${ }^{9}$ and (2) the Water Act. ${ }^{10}$ As of that date, the AER assumed regulatory functions from each of the ERCB, ESRD, and Alberta Energy, thereby becoming Alberta's single Regulator for upstream oil, gas, oil sands, and coal development.

Under REDA, the AER is tasked with providing for the efficient, safe, orderly, and environmentally responsible development and decommissioning of Alberta's energy resources. ${ }^{11}$ It is given broad powers to "do all things that are necessary for or incidental to the carrying out of"12 any of its functions or duties, including oversight over the abandonment and closure and subsequent remediation and reclamation of oil and gas infrastructure. ${ }^{13}$

\section{REGULATORY AUTHORITY OF THE AER UNDER}

THE PIPELINE ACT, THE OIL AND GAS CONSERVATION ACT, AND THE OIL SANDS CONSERVATION ACT

The AER has been delegated regulatory authority under four principal pieces of legislation: (1) the Pipeline Act, ${ }^{14}$ which regulates all pipelines falling within Alberta's jurisdiction; (2) the Oil and Gas Conservation Act, ${ }^{15}$ which pertains to the regulation of Alberta's wells and facilities; (3) the Oil Sands Conservation Act, ${ }^{16}$ under which the development of Alberta's oilsands is regulated; and (4) EPEA, under which the AER is tasked with promoting the protection, enhancement, and wise use of the environment. ${ }^{17}$

RSA 2000, c M-17, ss 106-13 (deals with geophysical approvals and other matters pertaining to seismic exploration).

RSA 2000, c P-40 (the regulatory functions and responsibilities assumed pertain to public lands dispositions related to energy developments).

OC 36/2014, (2014) A Gaz 1, 271.

RSA 2000, с E-12 [EPEA].

RSA 2000, c W-3.

REDA, supra note 5, s 2(1)(a). See also the OGCA, supra note 4, ss 4(a), 4(f) (effect the conservation of and prevent waste of Alberta oil and gas resources and control pollution); OSCA, supra note 4, ss 3(b), 3(e), 3(g) ("ensure the orderly, efficient and economical development in the public interest of the oil sands resources of Alberta," "assist the Government in controlling pollution in the development and production of the oil sands resources of Alberta," "ensure the observance, in the public interest, of safe and efficient practices in the exploration for and the recovery, storing, processing and transporting of oil sands").

REDA, ibid, s 14(1). See also the OGCA, ibid, s 7; OSCA, ibid, s 6.

REDA, ibid, ss 2(2)(g)-(h).

Supra note 4.

Supra note 4.

Supra note 4.

EPEA, supra note 9, s 2. 
Under the Pipeline Act (and the OGCA), the licensee (or licensee or approval holder) ${ }^{18}$ must discontinue or abandon a pipeline, or suspend or abandon a well or facility, when so directed by the Regulator or as required by the rules ${ }^{19}$ made under that legislation. ${ }^{20}$ The AER may order a pipeline, or well or facility, discontinued or abandoned, or suspended or abandoned, where it considers it necessary to protect the public or the environment. ${ }^{21}$ If the order is not complied with, the AER may authorize any person to discontinue or abandon the pipeline, or suspend or abandon the well or facility, ${ }^{22}$ or the AER may do so itself, on its own motion. ${ }^{23}$ The AER may determine the costs of discontinuation or abandonment (or suspension or abandonment) and prescribe a time for payment ${ }^{24}$ by the licensee of the pipeline ${ }^{25}$ or working interest participants, in accordance with their proportionate share in the well or facility. ${ }^{26}$

As well, under each of the Pipeline Act and the OGCA, the Regulator may sell or dispose of any installation or material (Pipeline Act), or any drilling, producing or operating equipment, installation or material (OGCA), found on the site or taken from the pipeline or from the well or facility, but shall not sell anything which it knows is owned by someone other than the licensee (Pipeline Act), or licensee, approval holder or working interest participant (OGCA). ${ }^{27}$ Any money received on the sale or disposal shall be applied first to the payment of any unpaid costs and penalties determined by the Regulator, second, to the extent any money remains, to the payment of any other outstanding debt owing to the Regulator from the licensee, approval holder, or working interest participant, and third, to pay persons who file a claim with the Regulator within six months after the date of the sale and who establish their entitlement to the money. ${ }^{28}$

Under the OSCA, if, in the opinion of the Regulator, an operation at an oil sands site or a suspension or abandonment of any scheme or operation is not in accordance with the terms or conditions prescribed by, or the rules made or an approval issued under the OSCA, the Regulator or any person authorized by it may enter the oil sands site and do whatever the Regulator considers necessary to ensure the compliance of the operation, suspension, or

Additionally, under section 27(2) of the OGCA, supra note 4, if the Regulator so directs (or, with the consent of the Regulator), a well or facility must (or may) be suspended or abandoned by a working interest participant other than the licensee or approval holder.

Under section 3(1) of the Pipeline Act, supra note 4, and section 10(1) of the OGCA, ibid (and section 10(2) with the approval of the Minister), the Regulator may make rules with respect to the matters listed. Pipeline Act, ibid, s 23(1); OGCA, ibid, s 27(1).

Pipeline Act, ibid, s 23(2); OGCA, ibid, s 27(3).

Note that under section 28 of the Pipeline Act, ibid, a person authorized to carry out discontinuation or abandonment operations is entitled to have access to the land for the purpose of carrying out the discontinuation or abandonment operations. A similar provision can be found at section 101 of the OGCA, ibid.

Pipeline Act, ibid, s 24; OGCA, ibid, s 28.

Pipeline Act, ibid, s 26(1)(a); OGCA, ibid, s 30(2).

Pipeline Act, ibid, s 26(1)(b).

OGCA, supra note $4, \mathrm{~s} 30(1)$. In the event the party responsible for payment fails to pay within the time prescribed by the Regulator, unless the Regulator orders otherwise, that party must pay a penalty equal to 25 percent of the costs. A certified copy of the AER's Order determining the costs and penalty may be filed and entered as a judgment of the Alberta Court of Queen's Bench and enforced accordingly: see Pipeline Act, ibid, ss 26(2), (4); OGCA, ibid, ss 30(3), 30(6).

Pipeline Act, ibid, s 27(3); OGCA, ibid, s 102(3). 
abandonment. ${ }^{29}$ Any costs incurred or authorized by the Regulator become a debt payable to the Regulator by the holder of the approval. ${ }^{30}$

In the case of a spill, when a substance escapes from a pipeline and it appears to the Regulator that it may not otherwise be contained and cleaned up forthwith, the Regulator may: (1) direct the pipeline operator or licensee to take any steps considered necessary to contain and clean up the substance and to prevent its further escape; ${ }^{31}$ (2) enter the area and conduct any operations it considers necessary; ;2 $^{32}$ or (3) engage any persons it considers necessary to conduct any operations on its behalf. ${ }^{33}$ When the Regulator enters an area to conduct operations, it may recover, deal with, and dispose of the escaped substance as if it were its property, and if any escaped substance is sold, apply the proceeds to pay the costs and expenses of the operations conducted by it. ${ }^{34}$ When any operations are conducted: (1) by an operator or licensee and the operator or licensee requests the Regulator to do so; or (2) by or on behalf of the Regulator, the Regulator may determine the costs and expenses of the operations and direct by whom and to what extent they are to be paid. ${ }^{35}$ Similar provisions dealing with the escape of substances from a well, facility, pipeline, or unidentified source may be found in the OGCA. ${ }^{36}$

\section{AUTHORITY OF THE AER UNDER EPEA}

Since 29 March 2014, ${ }^{37}$ the AER has also been responsible for administering the provisions of EPEA.

Part 5 of EPEA regulates the release of substances into the environment. Division 1 of Part 5 deals with releases of substances generally, Division 2 of Part 5 deals with contaminated sites, ${ }^{38}$ and Part 6 deals with conservation and reclamation. ${ }^{39}$

OSCA, supra note 4, s 19(1).

Ibid, s 19(2).

Pipeline Act, supra note 4, s 36(1)(a).

Ibid, s 36(1)(b); OGCA, supra note 4, s 104(1).

Pipeline Act, ibid, s 36(2)(c).

Ibid, s 36(2)(b).

Ibid, s 36(3).

Supra note 4, s 104(3).

On this day, the AER assumed the regulatory functions and responsibilities from ESRD under EPEA and the Water Act: see supra notes 9, 10.

Under section 125(1) of EPEA, supra note 9, the Director may designate an area a contaminated site if of the opinion that a substance may cause, is causing or has caused a significant adverse effect. For what constitutes a "significant effect" see Alberta Environment, Guideline for the Designation of Contaminated Sites under the Environmental Protection and Enhancement Act, April 2000 (Edmonton: Alberta Environment, 2000) at 2 [the Guideline]. The designation of a parcel of land as a "contaminated site” is viewed by Alberta Environment as a last resort. Under section 128(1) of EPEA, a person may prepare a remedial action plan and may enter into an agreement with the Director, with other persons responsible for the contaminated site, or with both, providing for remedial action and the apportionment of the costs. Under section 128(3), environmental protection orders (EPO) may not be issued if a remedial action plan has been carried out. In deciding whether to issue an EPO under section 129(1), the Director shall give consideration to the factors enumerated under section 129(2).

39 Under section 137 of EPEA, ibid, an operator must conserve and reclaim specified land and, unless exempted by the regulations, obtain a reclamation certificate. "Reclamation" and "conservation" are defined, respectively, in sections 1 (ddd) and 1(l). "Operator" is defined in section 134 (b) as including an approval or registration holder who carries on or has carried on an activity on "specified land" pursuant to an approval or registration, the holder of a licence, and a working interest participant in a well and an oil sands processing plant. "Specified land" is defined in section 134(f), which refers to the definition in section 1(t) of the Conservation and Reclamation Regulation, Alta Reg 115/1993, which includes the construction, operation, or reclamation of a well, an industrial pipeline, battery, or oil production site. An EPO may be issued by an inspector under section 140 at any time before the issuance 
Under Division 1 of Part 5 of EPEA, in addition to positive duties which are imposed, ${ }^{40}$ where the Director is of the opinion that a release of a substance may occur, is occurring, or has occurred, and that it may cause, is causing, or has caused an adverse effect, an environmental protection order (EPO) may be issued to "the person responsible for the substance," 41 defined in part in EPEA as including "the owner and a previous owner of the substance or thing," and "every person who has had charge, management or control of the substance or thing." 42 An EPO may order the person to whom it is directed to take a wide variety of measures that the Director considers necessary, including investigating the situation and restoring the area affected to a condition satisfactory to the Director. ${ }^{43}$ Emergency EPOs ${ }^{44}$ and emergency measures ${ }^{45}$ are also available to an inspector, an investigator, or the Director in the circumstances set out in the respective provisions.

Section 210 of EPEA, describes the enforcement orders the Director may take: "[w]here, in the Director's opinion, a person has contravened this Act," ${ }^{46}$ the Director may, "whether or not the person has been charged or convicted in respect of the contravention, issue an enforcement order which may order," among other things, "the suspension or cancellation of an approval," "the stopping or shutting down of any activity," and measures that must be taken in order to effect compliance with EPEA. ${ }^{47}$

If the person to whom an EPO or enforcement order is directed fails to comply with it: (1) the Minister may apply to the Alberta Court of Queen's Bench for an order directing that person to comply; ${ }^{48}$ and (2) the Director may take whatever action it considers necessary to

of a reclamation certificate where the performance or suspension of work is necessary to conserve and reclaim specified land. An EPO is also available where there is an adverse effect in a place other than, or a substance has escaped from, the specified land. An EPO may be issued after a reclamation certificate has been issued, in the circumstances set out in section 142, and an emergency EPO may be issued under section 143 where an inspector is of the opinion that an immediate and significant adverse effect may occur on specified land.

40 Under section 112 of EPEA, ibid, certain positive duties are imposed on "the person responsible for the substance.” These duties arise "[w]here a substance that may cause, is causing or has caused an adverse effect is released into the environment," and the person responsible "becomes aware or ought to have become aware of the release.” The duties include taking "all reasonable measures to repair, remedy and confine the effects of the substance, and remediate, manage, remove or otherwise dispose of the substance in such a manner as to prevent an adverse effect or further adverse effect, and restore the environment to a condition satisfactory to the Director." EPEA, ibid, s 113(1). Note that under section 118, where a remediation certificate is issued, no EPO requiring the doing of further work in respect of the same release of the same substance may be issued. Ibid, s 1 (tt).

Ibid, s 113(3). See also ss 129, 140-42 (regarding EPOs with respect to contaminated sites, conservation, and reclamation, respectively).

Under s 114(1) of EPEA, ibid,

where an inspector, an investigator or the Director is of the opinion that

(a) a release of a substance into the environment may occur, is occurring or has occurred, and

(b) the release may cause, is causing or has caused an immediate and significant adverse effect, the inspector, investigator or Director may issue an environmental protection order to the person responsible for the substance directing the performance of emergency measures that the inspector, investigator or Director considers necessary.

See also section 143 (emergency EPOs regarding conservation and reclamation).

Under section 115(1) of EPEA, ibid:

Where an inspector, an investigator or the Director is of the opinion that

(a) a release of a substance into the environment may occur, is occurring or has occurred, and

(b) the release may cause, is causing or has caused an immediate and significant adverse effect,

the inspector, investigator or Director may take any emergency measures that the inspector, investigator or Director considers necessary to protect human life or health or the environment. Except EPEA, ibid, ss 178-82 (all of which deal with waste).

Ibid, s 210.

Ibid, ss 213(1), 244(1). 
carry out the terms of the order. ${ }^{49}$ Costs incurred by the Director are recoverable in an action in debt from all persons named in the order ${ }^{50}$ on a joint and several basis, ${ }^{51}$ and constitute a charge against the lands involved. ${ }^{52}$

\section{B. THE FEDERAL STATUTORY AND REGULATORY FRAMEWORK}

Federal jurisdiction may arise: (1) in the case of Federal, interprovincial, or international undertakings; and (2) due to concurrent jurisdiction over environmental matters arising or situated within the provinces or regions. ${ }^{53}$

Interprovincial and international oil and gas infrastructure is regulated at the federal level by the National Energy Board (NEB). ${ }^{54}$ The NEB and its designated Inspection Officers are tasked with ensuring the safety of the public at large, as well as the protection of property and the environment. ${ }^{55}$ Broad powers are given under the NEB's enabling statute to access and inspect any facility and issue compliance orders where there are reasonable grounds to believe that a hazard or harm may result to the public or the environment. ${ }^{56}$ Compliance orders may require work associated with a pipeline or facility to be suspended until the hazardous situation has been remedied or the order rescinded, or they may go further to require the company or persons involved to take specified measures to ensure the safety or

Ibid, ss 214(1), 245(1).

Ibid, ss 214(2), 245(2), 246(2).

Ibid, ss 215, 240.

Ibid, s 216. Similarly, costs incurred in carrying out emergency measures under sections 115 or 152 of $E P E A$ are recoverable in an action in debt against the person who is responsible for the need to take the emergency measures, as are costs incurred by the government in, among other things, carrying out or causing to be carried out any preventive or remedial action made necessary by an act or omission that constituted an offence under EPEA, against any person convicted of an offence under EPEA: see EPEA, ibid, ss 223, 248.

Due to the diffuse nature of the environment, concurrent jurisdiction between the federal and provincial governments may arise where the exercise of federal powers and jurisdiction, including protection of the environment pursuant to the criminal law power, fisheries, navigation, and shipping, and international and interprovincial waters, falls within areas of provincial jurisdiction. See the Constitution Act, 1982, being Schedule B to the Canada Act 1982 (UK), 1982, c 11, ss 91(27), 91(12). See also Hogg, Constitutional Law of Canada, 5th ed (Toronto: Carswell, 2012) at 30-20 to 30-24. See also, Interprovincial Co-Operatives v The Queen, [1976] 1 SCR 477, cited in Hogg, ibid at 30-21; Friends of the Oldman River Society $v$ Canada, [1992] 1 SCR 3. Given the concurrent federal and provincial jurisdiction over the environment, there is also the potential for the application of federal legislation directed primarily at environmental and wildlife protection, and the concurrent involvement of a federal agency in the case of an environmental incident involving a provincially regulated pipeline, facility, well, or other oil and gas infrastructure. With respect to the harmonization of environmental regulation and enforcement as between the respective federal and provincial agencies, see e.g. Canadian Council of Ministers of the Environment, Statement of Interjurisdictional Cooperation on Environmental Matters; Canadian Council of Ministers of the Environment, A Canada-Wide Accord on Environmental Harmonization, online: Canadian Council of the Ministers of the Environment <www.ccme.ca/files/ Resources/harmonization/accord_harmonization_e.pdf>; Memorandum of Understanding Between National Energy Board and Energy Resources Conservation Board (24 March 2010), online: National Energy Board < www.neb-one.gc.ca/bts/ctrg/mmrndm/2010nrgrsrccnsrvtnbrd-eng.pdf>; Environment Canada, Canada-Alberta Environmental Occurrences Notification Agreement, online: Environment Canada <www.ec.gc.ca/ICPR-cepa/default.asp?lang=en\&n=A1BF062C-1>; Release and Environmental Emergency Notification Regulation, SOR/2011-90; Deposit Out of the Normal Course of Events Notification Regulation, SOR/2011-91.

National Energy Board Act, RSC 1985, c N-7 [NEB Act].

Ibid, s 49.

Ibid, ss 13 , 49(2). In addition to the broad powers afforded to the NEB under its enabling legislation, as a part of its Pipeline Abandonment - Financial Issues program, the NEB on 26 May 2009 issued its Reasons for Decision RH-2-2008, in which it directed all pipeline companies to begin setting aside funds for the abandonment of their facilities. On 29 May 2014, the NEB issued its Reasons for Decision MH001-2013, whereby it determined that by 1 January 2015, all NEB-regulated pipelines must have in place a mechanism for the accumulation of funds to pay for future pipeline abandonment. 
security of the public or of employees, or to protect property or the environment. ${ }^{57}$ In addition, the NEB may order a company to take any measures it considers necessary for the safety and security of a pipeline. ${ }^{58}$ Where an Inspection Officer has reasonable grounds to believe that a hazard to the safety or security of the public, or a detriment to property or the environment is being, or will be, caused by the operation or abandonment of a pipeline, the Inspection Officer may order the suspension of operations or any measures to ensure the safety or security of the public or to protect property or the environment. ${ }^{59}$

NEB orders may be enforced as an order of the Federal Court or the superior courts of any province. ${ }^{60}$ Penalties imposed under the NEB Act constitute a debt due to the Crown which, together with a certificate of non-payment issued by the Board, may be registered in the Federal Court or a court of competent jurisdiction and enforced accordingly. ${ }^{61}$

The NEB is also delegated regulatory powers under the Canada Oil and Gas Operations $A c t,{ }^{62}$ which applies to oil and gas operations in the Northwest Territories and Nunavut. ${ }^{63}$ Pursuant to COGOA, the NEB has broad powers to order or prohibit any person to do any act, matter, or thing that the person is or may be required to do under, or is contrary to, COGOA, the regulations under COGOA, or an order of the NEB. ${ }^{64}$

$\begin{array}{ll}57 & \text { Ibid, s 51.1(2). } \\ 58 & \text { Ibid, s 48(1.1). }\end{array}$

$59 \quad$ Ibid, s 51.1. Similar to the provincial framework, contravention of orders of the Board or Inspection Officers, or of the NEB Act itself, may result in offences and the imposition of monetary penalties and fines, either as a result of the offence or in the form of an administrative penalty: see ibid, ss 48(3), 51.4, 134, 136. Effective 10 April 2014, a number of amendments were made to the National Energy Board Onshore Pipeline Regulations, SOR/99-294 (OPR) including, under section 6.2(1), the requirement by an NEB-regulated company to appoint an “accountable officer” responsible, on the company's behalf, for the company's management system and related programs, including environmental protection and emergency management. As a result of the combination of sections 134(1)(a)(i), 136(1), and 137 of the NEB Act, and the Administrative Monetary Penalties Regulations (National Energy Board), SOR/2013138 (AMP Regulations), the latter of which came into force 3 July 2013, failure by the accountable officer to comply with those obligations under the $O P R$ that are set out in Schedule 1 of the AMP Regs, may give rise to administrative monetary penalties calculated in accordance with the formula set out in the AMP Regulations. The baseline penalty is adjusted upwards or downwards per the gravity values set out in section 4 of the AMP Regulations, subject to a daily maximum of $\$ 25,000$ for individuals in the case of ongoing violations. The violations potentially applicable in the case of an accountable officer which are set out in Part 2 of the AMP Regulations are classified as Type B which, according to Schedule 2, carry with them higher baseline penalties relative to the Type A violations. NEB Act, ibid, s 17.

Ibid, ss 151-52.

RSC 1985, c O-7 [COGOA]. On 1 April 2014, as a result of the devolution of the lands and resources in the Northwest Territories, the Government of the Northwest Territories (GNWT) will be responsible for the administration of onshore oil and gas development in the Northwest Territories. The NEB will remain the regulator for the offshore, which will remain under Canada's jurisdiction under COGOA. The NEB will also continue as regulator in the Inuvialuit Settlement Region, but under territorial legislation. A new office of the Regulator of Oil and Gas Operations is being integrated into the GNWT Department of Industry, Tourism and Investment.

COGOA also applies to oil and gas activities on Sable Island and submarine areas not within a province, within the internal waters of Canada, the territorial sea of Canada, or the continental shelf of Canada, other than oil and gas in the adjoining area, as defined in section 2 of the Yukon Act, SC 2002, c 7: COGOA, ibid, s 3 . However, the scope of this article does not address Canadian marine or offshore oil and gas operations. Note that a number of federal reforms pertaining to offshore oil and gas operations are included under Bill C-22, An Act respecting Canada's offshore oil and gas operations, enacting the Nuclear Liability and Compensation Act, repealing the Nuclear Liability Act and making consequential amendments to other Acts, 2nd Sess, 41st Parl, 2014, expected to become effective by 2017, including increasing absolute liability limits to $\$ 1$ billion and requiring proof of financial responsibility, upon application for an authorization, in the amount of $\$ 100$ million or such other amount as may be determined by the NEB.

COGOA, ibid, s 5.32. Note, this power does not apply to any act, matter or thing required by or contrary to any decision or order of the Committee established by section 6 of the Act: COGOA, ibid, s 5.33. 
COGOA also addresses liability for the costs of an environmental spill, which are to be borne by the party who obtained the authorization with respect to the work or activity carried on from which the spill emanated. ${ }^{65}$ Where that party does not take steps to rectify the spill, COGOA provides for various cost recovery mechanisms available to other persons who take such steps, as well as to the Crown. ${ }^{66}$

The Canadian Environmental Protection Act, $1999^{67}$ is a comprehensive piece of legislation that provides the framework for preventing pollution and protecting the environment. CEPA addresses the responsibility of users and producers of toxic substances and adopts a "polluter pays" principle. ${ }^{68}$ In accordance with CEPA, Environmental Protection Compliance Orders (EPC Orders) may be issued against any person who owns or controls a regulated substance, or who causes or contributes to an alleged contravention, to take directed action or to cease carrying on an impugned activity. ${ }^{69}$ If a person fails to comply with an EPC Order, an enforcement officer may take measures or cause them to be taken. As a result, another oil and gas industry participant may initially be responsible for the costs, although that party would retain the ability to pursue a civil action against the party responsible. ${ }^{70}$ In addition, the Crown has the ability to recover costs and expenses incidental to complying with an EPC Order from an array of participants. ${ }^{71}$

Liability may also arise as a result of a release of an enumerated toxic substance into the environment. ${ }^{72}$ Where there occurs, or is a likelihood of, a release into the environment of a substance specified in the List of Toxic Substances appearing as Schedule 1 to CEPA, any person who owns or has charge, management, or control of a substance immediately before its release, or its likely release, or who causes or contributes to the release or increases the likelihood of the release, must take all reasonable measures to protect the environment and public safety or to mitigate any danger to the environment. ${ }^{73}$ If a person fails to take the specified measures, an enforcement officer may take those measures, and the Crown may recover the costs and expenses reasonably incurred in the circumstances from the owner or person who had control of the substance, to the extent that the person knowingly or negligently caused or contributed to the release. ${ }^{74}$

Ibid, s 25(7).

Ibid, ss 25(7.1), 26.

SC 1999, с 33 [CEPA].

Ibid, Preamble.

Ibid, s 235.

Ibid, ss 239, 240(6).

Ibid, s 240.

Ibid, s 95. See also sections 169-70 (remedial measures for release of air pollution internationally); sections 179-80 (remedial measures for release of substance in international waters); sections 193-205 (environmental emergencies); sections 212, 214 (remedial measures for release of substance on Aboriginal lands or lands with a federal undertaking).

Ibid, s 95.

Ibid, ss 95(5), 98. 


\section{COMPARATIVE FRAMEWORK OF CANADA'S KEY OIL AND GAS PRODUCING Regions}

Similar to Alberta, the other key oil and gas producing provinces and regions ${ }^{75}$ have regulatory agencies responsible for monitoring the development of energy resources, and the effects of that development on the environment. As with Alberta, the other provincial and regional regulators are given broad powers to issue compliance orders and recover Environmental Costs from various participants.

Comparable to the AER's authority under the Pipeline Act, the OGCA, the OSCA, and $E P E A$, the other provincial and regional regulators may order the suspension or cessation of oil and gas activities where it is necessary to mitigate risk to public safety or to protect the environment. ${ }^{76}$ If a person fails to comply with an order, the respective agencies may undertake the work themselves and seek compensation from the person to whom the order was issued. $^{77}$

With respect to spills, similar to the situation in Alberta, the regulatory frameworks impose an obligation upon persons carrying out oil and gas activities to take positive steps to contain, remedy, and remediate any spills. ${ }^{78}$ In addition, the British Columbia Oil and Gas Commission (the OGC) may issue emergency orders directing any permit holder to assist in the implementation of measures to contain and eliminate spillage. ${ }^{79}$ The costs of remedial spillage measures are, for example, to be borne: (1) in British Columbia, by the party the OGC believes is responsible for the spillage or the likely source or cause of the spillage; ${ }^{80}$ and (2) in Manitoba, by the operator of the well or facility at which the spill occurred. ${ }^{81}$

The respective environmental management acts ${ }^{82}$ (collectively, the EMAs) set out the compliance and enforcement mechanisms available to address Environmental Costs. Under the various EMAs, the "person responsible" ${ }^{83}$ who bears liability is broadly defined,

75 See supra note 3. Their respective regulatory agencies are: the BC Oil and Gas Commission; the Saskatchewan Oil and Gas Conservation Board; the Manitoba Oil and Gas Conservation Board; and in regards to the Northwest Territories and Nunavut, the National Energy Board, as discussed above in the federal regulatory review.

76 British Columbia: Oil and Gas Activities Act, SBC 2008, c 36, s 49 [BC OGAA]. See also the Petroleum and Natural Gas Act, RSBC 1996, с 361; Saskatchewan: The Oil and Gas Conservation Act, RSS 1978, c O-2, ss 12, 17.01, 53.6 [Sask OGCA]. See also The Pipelines Act, 1998, SS 1998, c P-12.1; Manitoba: The Oil and Gas Act, CCSM c O34, ss 174, 176-77, 180 [Man OGA].

77 BC OGAA, ibid, s 50; Sask OGCA, ibid, s 17.03. See also Sask OGCA, ibid, s 17.04 (Minister's Power to take Immediate Action); Man OGA, ibid, ss 182(1), 184.

78 BC OGAA, ibid, s 37; The Environmental Management and Protection Act, 2002, RSS 2002, c E-10.21, s 7 [Sask EMPA]; Man OGA, ibid, s 119.

BC OGAA, ibid, s 52.

Ibid.

Man OGA, supra note 76, s 119(7).

Environmental Management Act, SBC 2003, с 53 [BC EMA]; Sask EMPA, supra note 78; The Environment Act, CCSM, c E125 [Man EA]. See also The Contaminated Sites Remediation Act, CCSM, c C205 [MB CSR] (which recognizes the "polluter pays principle” and contains similar compliance and enforcement provisions found in the Man EA); Environmental Protection Act, RSNWT 1988, c E-7 [NWT EPA] (which applies in both the NWT and Nunavut).

83 This is subject to the provisions contained in the NWT EPA, which do not expressly provide a definition of "person responsible," yet the clause operates in much the same manner. Pursuant to the NWT EPA, the inspector may issue an order to any person whose actions may increase the likelihood of a discharge, or the owner or person in charge, management, or control of the contaminant: see NWT EPA, ibid, s 4(2). 
encompassing current and previous owners or operators of the site ${ }^{84}$ or substance, ${ }^{85}$ persons who produced or transported the substance in a manner that caused the site to become contaminated, ${ }^{86}$ as well as the owner of a pollutant or any other person having charge, management, or control of a pollutant. ${ }^{87}$ Certain of the EMAs specifically identify categories of persons who are not responsible for remediation, which include an owner or operator who can establish that the site was already contaminated at the time it acquired its interest and that it had no knowledge of the contamination despite reasonable due diligence efforts. ${ }^{88}$

Pursuant to the British Columbia and northern EMAs, ${ }^{89}$ at the request of the person responsible for environmental contamination, the regulator may enter into a voluntary remediation agreement providing for financial or other contributions by the responsible person and a schedule governing the remediation. ${ }^{90}$ In British Columbia, if responsible persons comply with the terms of a voluntary remediation agreement, they are discharged from further liability, but not relieved from any possible actions commenced against them under other legislation or at common law. ${ }^{91}$ In contrast, although the northern EMAs provide that persons shall not be prosecuted if they comply with a remediation agreement, the provisions are unclear as to the effect of such an agreement on the rights of third parties, stating only that the prosecution of a person who is a party to an agreement is not precluded with respect to "matters not covered by the agreement."

In comparison, in Saskatchewan, where there are multiple parties responsible for a discharge on a contaminated site, the parties have a duty to enter into a written remediation agreement with each other, which shall provide for the remedial action that must be taken and the apportionment of the ensuing costs between them. ${ }^{93}$

The environmental regulators have the authority to issue EPOs directing broad remedial measures ${ }^{94}$ and, generally, to carry out the orders themselves and recover the costs incurred. ${ }^{95}$ With the exception of the northern EMAs, the orders may be registered as judgments with the various provincial courts and enforced accordingly. ${ }^{96}$ In addition, in British Columbia the director also has the authority to issue pollution prevention and abatement orders where it is satisfied that an operation has been or is being performed in a manner that is likely to cause, or is actually causing pollution. ${ }^{97}$ The orders may direct a party to carry out any measures that are reasonably necessary to prevent or abate the pollution, at that party's expense. $^{98}$

BC EMA, supra note 82, s 45; Sask EMPA, supra note 78, s 2(w)(iii).

Sask EMPA, ibid, s 2(w)(i).

BC EMA, supra note 82, s 45; Sask EMPA, ibid, s 2(w)(ii).

Man EA, supra note 82, s 1(2).

BC EMA, supra note 82, s 46(d); Sask EMPA, supra note 78, s 2(w)(x).

The "northern EMAs" is reference to the EMAs of the Yukon, the Northwest Territories, and Nunavut. BC EMA, supra note 82, s 51(1); NWT EPA, supra note 82, s 11.1.

BC EMA, ibid, s 51(2).

NWT EPA, supra note 82, ss 11.1(4), (6).

Sask EMPA, supra note 78, s 14(2).

BC EMA, supra note 82, s 85; Sask EMPA, ibid, ss 46, 47; Man EA, supra note 82, ss 24, 24.1; NWT

EPA, supra note 82, ss 4, 5.1, 6 .

BC EMA, ibid, s 59; Sask EMPA, ibid, s 51; Man EA, ibid, s 24.2; NWT EPA, ibid, ss 7(2), 16.

Sask EMPA, ibid, s 53.

BC EMA, supra note 82, ss 81, 83.

Ibid, ss 81(1), 83(2). 
Where a party contravenes the provisions of the provincial and regional regulatory legislation, it may be found guilty of an offence and liable to a prescribed fine. ${ }^{99}$ In some instances, where a party is convicted of an offence and the court is satisfied that monetary benefits accrued to the party as a result, a penalty in addition to a fine may also be imposed. ${ }^{100}$

\section{INSOLVENCY AND ORPHAN FUNDS}

The allocation of costs may be affected by an insolvency, which potentially entails what has been termed the "untidy intersection" of the Companies' Creditors Arrangement Act ${ }^{101}$ and the powers of regulators to make orders directing the remediation of contaminated property. ${ }^{102}$ As a result of the Supreme Court of Canada's relatively recent ruling in Newfoundland and Labrador v AbitibiBowater Inc., ${ }^{103}$ EPOs and other regulatory orders that, in effect, constitute a financial liability, are to be considered "claims" within the meaning of the $C C A A$, to which the claims process and stay of proceedings set out in the CCAA apply. ${ }^{104}$

In AbitibiBowater, the majority of the Court held that in the case of an environmental order not framed in monetary terms, courts must determine, in light of the factual matrix and the applicable statutory framework, whether the facts support the existence of a duty that will ripen into a financial liability owed to the regulatory body that issued the order. ${ }^{105}$ To this end, a three-part test was set out to determine whether an environmental order is to be considered a claim, subject to compromise within the CCAA insolvency process: (1) there must be a debt, liability, or other obligation to a creditor; (2) the obligation needs to have been incurred prior to the time limit for inclusion in the insolvency process; and (3) it must be possible to attach a monetary value to the debt. ${ }^{106}$

AbitibiBowater turned on the third requirement, as to whether the remediation order could be expressed in monetary terms. ${ }^{107}$ It was held by the majority that in the context of an environmental order, to be a claim there must be sufficient indications that the regulatory body will ultimately be forced to perform the remediation work itself and subsequently assert

BC OGAA, supra note 76, s 86; Sask OGCA, supra note 76, s 59; Sask EMPA, supra note 78, s 74; Man OGA, supra note 76, s 199; Man EA, supra note 82, s 33; NWT EPA, supra note 82, ss 12-12.1. BC OGAA, ibid, s 92; Sask OGCA, ibid, s 59(3); Man EA, ibid, s 36(d).

Companies' Creditors Arrangement Act, RSC 1985, c C-36 [CCAA].

Re Nortel Networks Corp, 2013 ONCA 599, 368 DLR (4th) 122 [Nortel].

2012 SCC 67, [2012] 3 SCR 443 [AbitibiBowater]. AbitibiBowater was subsequently applied by the Ontario Court of Appeal in its two concurrent decisions in Nortel, ibid and Re Northstar Aerospace Inc, 2013 ONCA 600, 8 CBR (6th) 154 [Northstar]. Following the release of the decision in AbitibiBowater but before the Ontario Court of Appeal decided the appeals in Nortel and Northstar, the parties were given leave to file fresh factums and evidence, upon which the Ontario Court of Appeal based its decisions.

See CCAA, supra note 101, s 11.1, which provides that subject to the Court ordering otherwise under section 11.1(3), an Order staying proceedings under section 11.02 does not affect "a regulatory body's investigation in respect of the debtor company or an action, suit or proceeding that is taken in respect of the company by or before the regulatory body, other than the enforcement of a payment ordered by the regulatory body or the court."

AbitibiBowater, supra note 103 at para 3.

Ibid at paras 26-31.

As did Nortel, supra note 102 and Northstar, supra note 103. 
a monetary claim to have its costs reimbursed. ${ }^{108}$ In assessing this issue, the factors to be considered include whether the impugned activities are ongoing, whether the debtor is in control of the property, and whether the debtor has the financial means to comply with an order. $^{109}$

In response to the province's position that this treatment of a regulatory order would have the effect of undermining the "polluter-pay principle," the majority noted that the claims process did not extinguish the environmental obligation of the debtor, but only made the claim subject to the insolvency process. If accepted, the province's position would result not only in a super-priority, but in the acceptance of a "third-party pay" principle (that is, creditors) in place of the polluter-pay principle. ${ }^{110}$

It was also held that the province cannot disturb the priority scheme established under federal insolvency legislation, and that to exempt an environmental order from the legislation (beyond the specific and limited priority afforded under the $C C A A^{111}$ ) would have the effect of conferring upon it a higher priority than provided in the CCAA. ${ }^{112}$

In the end, the provinces and regions may be responsible for the costs of aging infrastructure where a company is insolvent. This liability is subject to being offset to the extent access is available to "orphan funds," established for the purpose of paying costs related to suspension, abandonment, remediation, and reclamation of orphaned facility sites or wells. ${ }^{113}$

In Alberta, the orphan fund is financed through levies prescribed by the Regulator taking into account the number of wells and unreclaimed well sites, as well as any amounts for the purposes of addressing any deficiencies or shortfalls. ${ }^{114}$ The levies are made on licensees and approval holders included in the AER's Licensee Liability Rating, Large Facility Liability

AbitibiBowater, supra note 103 at para 36. See also Nortel, ibid at para 31; Northstar, ibid at para 14.

In Northstar, the following is stated:

I adopt my review of the AbitibiBowater Inc., Re decision as set out in Nortel Network Corp., Re.

Briefly stated, the Supreme Court decided that ongoing environmental remediation obligations may

be reduced to monetary claims that can be compromised in CCAA proceedings in two circumstances: (1) where the province has performed the remediation work and advances a claim for reimbursement, or (2) where the obligation may be considered a contingent or future claim because it is "sufficiently certain" that the province will do the work and then seek reimbursement. AbitibiBowater, ibid at para 38. In Northstar, ibid, because there was no subsequent purchaser who could be ordered to undertake the remediation, and since the regulator had commenced the remediation itself, it was held that the regulatory orders were in substance a claim provable in bankruptcy. In Nortel, ibid, unlike the situation in AbitibiBowater and Northstar, there existed other current and former owners of all but Nortel's London site, against whom the environmental order had been issued jointly and severally. As a result, the Ontario Court Appeal held that apart from the London site, it was not sufficiently certain that the regulator would conduct the remediation itself. AbitibiBowater, ibid at para 40.

111 See CCAA, supra note 101, s 11.8(8) (which provides regulators with a super-priority for remediation costs incurred, but only over the insolvent's real property related to the activity which caused the contamination). AbitibiBowater, supra note 103 at para 19.

OGCA, supra note 4, Part 11; The Oil and Gas Conservation Regulations, 2012 RRS, c O-2, Reg 6; Man OGA, supra note 76; BC OGAA, supra note 76. In Alberta, a well, facility, or pipeline in the Licensee Liability Rating Program (LLRP) is eligible to be declared an orphan when the licensee becomes insolvent or defunct, and the AER designates it as such (provided it meets the criteria outlined in section 70(2) of OGCA), at which time it will be considered an orphan for all aspects of the LLRP: suspension, abandonment, remediation, and reclamation. 
Management, and Oilfield Waste Liability Programs, based on the participants' deemed liability for the year. ${ }^{115}$

Whereas Saskatchewan's orphan fund levy is substantially the same as Alberta's, British Columbia has adopted a different approach. In British Columbia, producers must pay to the government a tax equivalent based on a dollar amount per unit of production. ${ }^{116}$ Producers are invoiced on a monthly basis for the applicable levy. ${ }^{117}$

The orphan fund levies are a significant source of revenue for governments to assist in allaying the increasing costs associated with abandonment, reclamation, and remediation of oil and gas infrastructure. In Alberta, for example, over \$223 million has been collected since 1992 to fund orphan activities. ${ }^{118}$ For the past five years, the orphan fund levy in Alberta has been approximately $\$ 12$ million. ${ }^{119}$ It is possible that the increasing costs of aging oil and gas infrastructure are reflected in Alberta’s recently issued 2014/15 levy of \$15 million. ${ }^{120}$

\section{The Private Cost Recovery Framework}

Generally, and with some limited exceptions, the public framework discussed in Part I does not address whether or how Environmental Costs are shared among private industry participants. ${ }^{121}$ The issues that arise when considering the sharing of Environmental Costs among private industry participants are complex and can lead to significant uncertainty. ${ }^{122}$ This part of the article will provide a broad overview of three main issues. First, it will address the threshold question of ownership and the contractual obligations related to the administration of assets. Second, it will address the sharing of liability for Environmental Costs among current owners of the assets. Third, it will address the potential liability of former owners of the assets.

The Licensee Liability Rating Program (LLRP), administered by the AER, was introduced by the Alberta Energy and Utilities Board in 2000. The LLRP governs most conventional upstream oil and gas wells, facilities, and pipelines included within the scope of the Orphan Fund, as specified in Appendix 1 of AER Directive 006. Under the LLRP, the ratio of deemed assets to deemed liabilities is calculated for each licensee on a monthly basis to estimate the degree of risk associated with that licensee's abandonment and reclamation obligations. Licensees with unacceptable risks are required to either reduce their liabilities or to post security deposits for abandonment and reclamation costs. See Alberta Energy Regulator, Directive 006: Licensee Liability Rating (LLR) Program and Licence Transfer Process (2013), online: Alberta Energy Regulator < https://www.aer.ca/documents/directives/Directive 006_May2013.pdf>.

116 BC OGAA, supra note 76, ss 45(3), 47(1).

117 Fee, Levy and Security Regulation, BC Reg 278/2010, s 7.

Orphan Well Association, 2013/14 Annual Report, online: Orphan Well Association <www.orphan well.ca/OWA\%202013-14\%20Ann\%20Rpt\%20Final.pdf> at 4.

$119 \quad$ Ibid at 5 .

120 AER, Bulletin 2014-02, “2014 Orphan Fund Levy” (6 January 2014), online: Alberta Energy Regulator $<$ www.aer.ca/rules-and-regulations/bulletins/aer-bulletin-2014-02>.

121 In British Columbia v Canadian Forest Products Ltd, 2004 SCC 38, [2004] 2 SCR 74 at para 155, Justice Binnie for the majority, confirmed that "there is no reason to neglect the potential of the common law, if developed in a principled and incremental fashion, to assist in the realization of the fundamental value of environmental protection.”

122 There are several other ways that Environmental Costs may be shared by private industry participants, which are outside the scope of this article. For example: (1) where insurance is available and in place, owners may have claims against their insurers; (2) where the Environmental Costs are caused or contributed to by non-owners, for example goods and services providers (pipe manufacturers, drilling service companies, etc.) or other third parties (adjacent landowners, mineral rights owners, etc.) then owners may have claims pursuant to sale of goods legislation, contract, or tort; (3) regulated utilities (including, for example, pipelines) may have legislative or contractual mechanisms available to them to recover Environmental Costs from their customers; (4) individual directors or officers of industry participants may be held responsible for Environmental Costs. 


\section{A. THE THRESHOLD OWNERSHIP ISSUE}

When considering responsibility for Environmental Costs, a primary consideration is who owns the property that is the subject of, or caused the need for, the work. Determining ownership in the Canadian oil and gas industry is often complicated by the fracturing of ownership in oil and gas leases, lands, and facilities, as well as the transfer of those fractured interests over time.

Ownership can be a full answer to the question of whether a particular party is liable for Environmental Costs. A party may avoid responsibility if it never owned, or no longer owns, an interest in the relevant property. Two Alberta cases have already been decided on this threshold issue in the context of oil and gas Environmental Costs. ${ }^{123}$ They highlight that each case will depend on its own facts and a proper interpretation of the relevant contract within its commercial context. ${ }^{124}$

In Anadarko, ${ }^{125}$ the issue was whether an abandoned battery had been acquired by Canadian Natural Resouces Ltd (CNRL) pursuant to a purchase and sale agreement. Some of the leased lands included in the transaction had previously contained a battery that had been abandoned by one of Anadarko's predecessors. Following the sale to CNRL, Anadarko, as the licence holder of the former battery, received a notice demanding that it remediate the site that had contained the former battery as it showed evidence of salt water and hydrocarbon contamination.

The case turned on the Court's interpretation of the definition of the "Assets" conveyed in the purchase and sale agreement and several indemnity provisions. Despite an environmental indemnity provision in favour of the vendor, Anadarko, which captured both accrued and accruing environmental liabilities, CNRL was not held liable. The Court determined that in order for the indemnity to be invoked, it must "pertain to the Assets or to any well located on the Lands." After reviewing the definition of Assets, which included the usual categories of "Petroleum and Natural Gas Rights," "Tangibles," and "Miscellaneous Interests," the Court concluded that the definition of Assets did not include the abandoned well battery. ${ }^{126}$

In Talisman, ${ }^{127}$ the issue was whether Talisman was responsible for a share of Environmental Costs resulting from sulphur stockpiles next to the East Crossfield Gas Plant.

Anadarko Canada Corp v Canadian Natural Resources Ltd, 2006 ABQB 590, [2006] AJ No 959 (QL) [Anadarko]; Talisman Energy Inc v Esprit Exploration Ltd, 2013 ABQB 132, 75 Alta LR (5th) 219 [Talisman]. See also Re Dalhousie Oil Co, [2010] AEUBD No 187 (QL) (ERCB) [Dalhousie].

See also Creston Moly Corp v Sattva Capital Corp, 2014 SCC 53, 373 DLR (4th) 393; ATCO Electric Ltd v Energy and Utilities Board (Alta), 2004 ABCA 215, 361 AR 1; Omers Energy Inc v Alberta (ERCB), 2011 ABCA 251, 513 AR 292; Tercon Contractors Ltd v British Columbia (Transportation and Highways), 2010 SCC 4, [2010] 1 SCR 69 [Tercon]; King v Operating Engineers Training Institute of Manitoba Inc, 2011 MBCA 80, 270 Man R (2d) 63; Canadian Natural Resources Ltd v Encana Oil \& Gas Partnership, 2008 ABCA 267, 440 AR 338; Moore Realty Inc v Manitoba Motor League, 2003 MBCA 71, 173 Man R (2d) 300; Alberta Energy Co Ltd v Goodwell Petroleum Corp, 2003 ABCA 277, 339 AR 201; Consolidated-Bathurst Export Ltd v Mutual Boiler and Machinery Insurance Co, [1980] 1 SCR 888; Eli Lilly \& Co v Novopharm Ltd, [1998] 2 SCR 129; Dow Chemical Canada Inc v Shell Chemicals Canada Ltd, 2010 ABCA 126, 477 AR 112.

Anadarko, supra note 123.

Ibid at para 33.

Supra note 123. 
Talisman had, several years earlier, acquired oil and gas assets, including an interest in the East Crossfield Gas Plant. Again, the case turned on a detailed interpretation of the purchase and sale agreement and the definition of “Assets," as well as the commercial context, which included numerous inter-connected historical agreements dating back to the 1960s. The Court concluded that the sulphur stockpiles were not included in the definition of "Assets" acquired by Talisman. Talisman was, therefore, not liable as an owner of the stockpiles or under environmental indemnities that were limited to or "pertaining to" the assets acquired. ${ }^{128}$

Anadarko and Talisman highlight that industry participants should be careful in considering how they define assets being conveyed in a transaction. Special care should be taken where an asset has reached the end of its operating life, has already had some reclamation, remediation, or abandonment work completed, or is no longer a productive asset. Many transactions involve the acquisition of producing or prospective assets and interests and the parties may lose sight of old, unproductive, already reclaimed or abandoned assets. Such assets, and their potential future Environmental Costs, should be specifically addressed.

These cases also highlight the difficulties where ownership of assets is unclear, complex, or has a long history of fractured or transferred ownership interests. Tracking ownership can be complicated by lost records, poor record-keeping, changing operators and operator practices, insolvency of working interest participants or co-owners, and even the longstanding perpetuation of mistakes in the administration of the assets. These issues are heightened for aging infrastructure. For example, the historical tracking of the ownership of field gathering systems has been inconsistent at best and, in some cases, is non-existent. As such industry infrastructure ages and requires expenditure of Environmental Costs in the future, there will likely be significant litigation over who owns the infrastructure, which contracts govern, and who is responsible to pay for Environmental Costs.

\section{B. SHARING OF Costs AMONg CURRENT OWNERS}

A current co-owner, usually an operator, will have several potential avenues for recovery of Environmental Costs from other current co-owners. Claims made pursuant to statute, industry standard form or other contracts, common law property principles, and tort will each have their own advantages and disadvantages and are addressed briefly below.

\section{StATUtORy REMEDiES AND CAUSES OF ACTION}

Some statutory frameworks go beyond preserving common law rights and provide current owners with a statutory cause of action. For example, in Saskatchewan, there is a statutory cause of action by which an owner could potentially claim against a co-owner for certain losses arising out of discharges or other breaches of statutory duties. ${ }^{129}$ In British Columbia, in the case of a contaminated site, any "responsible person" may commence an action or a proceeding to recover reasonably incurred costs of remediation from one or more other 
responsible persons, which includes current owners. ${ }^{130}$ Under CEPA, any person who has suffered loss or damage as a result of conduct that contravenes any provision of CEPA may bring an action to recover certain losses from the "person who engaged in the conduct."131 EPEA has a similar provision where a person has been convicted of an offence. ${ }^{132}$

Some jurisdictions provide a statutory remedy through administrative tribunals. For example, the Manitoba Contaminated Sites Remediation Act ${ }^{133}$ provides a procedure by which persons responsible for remediation can have the Manitoba Clean Environment Commission apportion responsibility for the costs of the remediation. ${ }^{134}$ In Alberta, the "person who conducted the suspension, abandonment or reclamation" 135 of a well or facility can apply to the AER to determine and allocate those costs to "each working interest participant in accordance with its proportionate share." ${ }^{\text {136 }}$ A pipeline operator or licensee, or specific other persons, can request the AER to determine the costs to contain and clean up an escaped substance, and to direct by whom and to what extent those costs are to be paid. ${ }^{137}$ The limited recent reported decisions on these provisions indicate that they are rarely used by industry participants. ${ }^{138}$ Current owners should carefully consider the advantages and disadvantages of engaging statutory causes of action or administrative procedures. ${ }^{139}$

\section{UNDER THE CAPL OPERATING PROCEDURE}

The Canadian Association of Petroleum Landmen (CAPL) model form Operating Procedure (the "Procedure") has been a vital part of Canada's oil and gas industry for decades. Under its various forms, the operator generally has the right and duty to control and manage joint operations on behalf of the parties. ${ }^{140}$ In carrying out its duties, an operator may make any expenditure for the joint account that it considers necessary and prudent, but not

BC EMA, supra note 82, s 47(5). See also Gehring v Chevron Canada Ltd, 2006 BCSC 1639, 25 CELR (3d) 167 [Gehring]. There are some restrictions and statutory defences applicable to such an action.

131 CEPA, supra note 67, s 40.

132 EPEA, supra note 9, s 219. See also BC OGAA, supra note 76, s 90, which provides that "[i]f a person is convicted of an offence under this Act, then, in addition to any other penalty, the court may order the person to pay compensation or make restitution."

$133 \quad$ MB CSR, supra note 82.

134 However, pursuant to section 3(3) this Act does not apply to a site to which the provisions of The Oil and Gas Act, CCSM c O34 or The Mines and Minerals Act, CCSM c M162 respecting the rehabilitation of land apply. See MB CSR, ibid, s 3(3).

135 The definition of reclamation is broad enough to include site remediation costs.

136 OGCA, supra note 4, s 30(2). See also section 104 (a licensee, approval holder or operator who has taken steps to contain and clean up an escaped substance can apply to the AER).

137 Pipeline Act, supra note 4, s 36(3). In the case of discontinuance or abandonment costs, the AER does not appear to have jurisdiction to award those costs against anyone other than the licensee of the pipeline: see Pipeline Act, ibid, s 26.

138 See e.g. Re Prince Resource Corp, 2003 CarswellAlta 2098 (WL Can) (AEUB); Dalhousie, supra note 123. See also Domtar Inc v British Columbia (Director, Environmental Management Act) (2013),78 CELR (3d) 311 (BC Environmental Appeal Board) (Director issued remediation order pursuant to the BC EMA, supra note 82, s 48. The parties appealed the order. The appeal was scheduled to be heard in September and October of 2013 and at the time of writing this article there was no written reported decision).

139 For example, statutory causes of action may eliminate the need to prove a contractual or other relationship and could provide evidentiary shortcuts. Administrative proceedings may be a less cumbersome, more efficient, and faster method of adjudicating disputes, but may have much more limited rights of appeal or review. See e.g. REDA, supra note 5, ss 36(a)(iv), 38, 45, 56. Further, a decision before an administrative tribunal such as the AER may give rise to issue estoppel that may preclude litigating the same issues before the courts.

140 CAPL, 2007 CAPL Operating Procedure, online: CAPL <www.landman.ca/landman_tools/operating procedure2007.php> cls 3.01A, 5.02, 5.06; 1990 CAPL Operating Procedure, cls 301, 502, 506. 
in excess of the applicable threshold. ${ }^{141}$ As Environmental Costs will usually exceed the thresholds, an Authorization for Expenditure (AFE) will often be required. Recovery of Environmental Costs from a co-owner will often be through the use of the cost recovery provisions under the AFE procedure. ${ }^{142}$

There are exceptions to the AFE requirement that may impact responsibility for Environmental Costs. An AFE has never been required where the expenditure is necessary by reason of an event endangering life or property. Those costs can be charged to the joint account without prior authorization. ${ }^{143}$ In the 1990 Procedure, an exception to the AFE requirement was added where an expenditure is required by the "Regulations"144 and the failure to make the expenditure could result in the prosecution of the operator. ${ }^{145}$ In the 2007 Procedure, the provisions related to emergency situations were further strengthened; the operator does not require an AFE where the operator reasonably determines that an emergency exists or is imminent, and the expenditure is necessary for the preservation of life or property, or to prevent or mitigate pollution or other "Environmental Liabilities."146 Further, an exception exists if the operator reasonably determines that the expenditure is

required by the Regulations (including any such expenditure to mitigate pollution or other Environmental Liabilities or to complete Abandonment, in due course, of any surface location associated with a Joint Operation or any Joint Property), where failure to make that expenditure at that time could result in prosecution of the Operator or the imposition of enforcement actions, penalties or any other material adverse formal consequence on the Operator under the Regulations. ${ }^{147}$

All such expenses can be incurred for the joint account without prior authorization.

Where an AFE is required, approval of an AFE generally constitutes a party's approval of all expenditures necessary to conduct the operations described therein. ${ }^{148}$ Potential issues arise where there have been cost overruns and supplemental AFEs, or where it is alleged that the AFE does not reasonably describe the operations, contains misrepresentations, or was negligently prepared. The determination of those issues will depend on which Procedure

See e.g. 2007 CAPL Operating Procedure, ibid, cl 3.01B (\$50,000); 1990 CAPL Operating Procedure, ibid, cl 301(b) (\$25,000). 2007 CAPL Operating Procedure, ibid, cls 5.03, 5.06; 1990 CAPL Operating Procedure, ibid, cls 503, 506.

CAPL, 1974 CAPL Operating Procedure, cl 301; 1981 CAPL Operating Procedure, cl 301; 1990 CAPL Operating Procedure, ibid, cl 301(b); 2007 CAPL Operating Procedure, ibid, cl 3.01B.

The definition contained in the 1990 CAPL Operating Procedure, ibid, is substantively the same as the definition contained in the 2007 CAPL Operating Procedure, ibid: "Regulations" means all statutes, laws, rules, orders and regulations in effect from time to time and made by governments or governmental boards or agencies having jurisdiction over the joint lands and over the operations to be conducted thereon.

1990 CAPL Operating Procedure, ibid, cl 301(b); 2007 CAPL Operating Procedure, ibid, cl 3.01B.

"Environmental Liabilities" has a very broad definition. It means "all liabilities pertaining to the Joint Property in respect of the environment, whether or not relating to a breach of the Regulations and whether or not resulting from Operations," and includes a specific list of enumerated liabilities related to, among other things, "transportation, storage, use or disposal of toxic or hazardous substances or hazardous, dangerous or non-dangerous oilfield substances or waste; the release, spill, escape or emission of toxic or hazardous substances; [or] any other pollution or contamination of the surface, substrate, soil, air, ground water, surface water or marine environments": see 2007 CAPL Operating Procedure, ibid, cl 1.01. 2007 CAPL Operating Procedure, ibid, cl 3.01B. 143, cl 301; 1990 CAPL Operating Procedure, supra note 140, cl 301; 2007 CAPL Operating Procedure, ibid, cl 3.01C. 
applies. This has been the subject of significant judicial and academic consideration over the years, all of which increasingly favours protection of the operator from challenge. ${ }^{149}$

In the event a non-operator does not pay its share of Environmental Costs, an operator may seek reimbursement from the other non-operators. ${ }^{150}$ Under the 2007 Procedure, the operator also has the option to designate a defaulting party to be a non-participating party. ${ }^{151}$ The effect of the various default provisions is that the liability for Environmental Costs may sometimes be shifted from a defaulting party to the other non-operators.

Responsibility for Environmental Costs may also be affected where "independent operations”152 are taken. Broadly speaking, and subject to specific rules, a party that elects to participate will participate only to the extent of its working interest as a proportion of all participating working interests, plus any unassumed percentage it takes on. ${ }^{153}$ Subject to exceptions for specific types of independent operations, or the allocation of costs to different operations or property not subject to the operating agreement, the non-participating parties generally will not be liable for the Environmental Costs related to operations or a well in which they did not participate. ${ }^{154}$ Non-participating parties will likely only become liable for Environmental Costs after any applicable penalties or cost recoveries have been paid and the non-participating party elects, or is deemed to elect, to participate in the well that was the subject of the independent operation. ${ }^{155}$

Finally, the Procedure has specific provisions addressing well abandonment that can impact responsibility for Environmental Costs. A party may give notice of its intention to abandon a well held for the joint account in certain circumstances. ${ }^{156}$ A party receiving the notice must elect either to participate in the abandonment or take over the well, failing which it is deemed to have taken over the well. Parties participating in the abandonment are deemed to have assigned to the non-abandoning parties, on an "as is, where is" basis, the abandoning parties' working interests in the well, the surface rights and other joint property serving that well, and the right to produce the well. ${ }^{157}$ The 2007 Procedure goes further to say that the parties receiving the assignment are responsible for all abandonment obligations and environmental liabilities that accrued and are accruing respecting that well. ${ }^{158}$ The non-

Renaissance Resources Ltd v Metalore Resources Ltd (1984), 53 AR 289 (QB); Novalta Resources Ltd $v$ Ortynsky Exploration Ltd (1994), 151 AR 161 at para 22 (QB); Passburg Petroleums v San Antonio Explorations Ltd (1987), 57 Alta LR (2d) 57 (QB); Powermax Energy Inc v Argonauts Group Ltd, 2003 ABQB 71, 334 AR 1; CAPL, 2007 CAPL Operating Procedure, Annotations, online: CAPL <www. landman.ca/landman_tools/operating_procedure2007.php\#> at 13 [2007 CAPL Annotations]; Craig Spurn, Jana Prete \& Melissa Zerebeski, “The 2007 CAPL Operating Procedure” (2009) 46:2 Alta L Rev 427; James A Maclean, “The 1990 CAPL Operating Procedure: An Overview of the Revisions” (1992) 30:1 Alta L Rev 133.

2007 CAPL Operating Procedure, supra note 140, cl 5.06; 1990 CAPL Operating Procedure, supra note 140, cl 506; 2007 CAPL Annotations, ibid at 21. 2007 CAPL Operating Procedure, ibid, cl 5.05B(f)(ii).

An independent operation is an operation carried out by less than all of the parties with a working interest in the subject matter of the independent operation.

2007 CAPL Operating Procedure, supra note 140, cl 10.02C.

2007 CAPL Operating Procedure, ibid, cls 9.04, 10.08E; 2007 CAPL Annotations, supra note 149 at 27; Spurn, Prete \& Zerebeski, supra note 149 at 463-64.

See e.g. 2007 CAPL Operating Procedure, ibid, cls 10.06B(e), 10.06C, 10.06E, 10.07A, 10.07C, 10.08; 2007 CAPL Annotations, ibid at 32-33.

2007 CAPL Operating Procedure, ibid, cl 12.00; 1990 CAPL Operating Procedure, supra note 140, cl 1201.

2007 CAPL Operating Procedure, ibid, cl 12.02A; 1990 CAPL Operating Procedure, ibid, cl 1202. 2007 CAPL Operating Procedure, ibid, cl 12.02C. 
abandoning parties are, therefore, at risk for all Environmental Costs regardless of when the environmental liabilities accrued.

\section{FACILITY AGREEMENTS ${ }^{159}$}

Oil and gas industry participants have commonly made and increasingly make provision in commercial agreements to allocate liabilities, and to ensure there are sufficient funds and adequate procedures to address the abandonment liabilities of midstream facilities. Responsibility for abandonment and remediation will generally remain with the facility owners. Various commercial arrangements determine how liability is allocated among the owners, users, and other stakeholders in the facilities. ${ }^{160}$

Co-ownership agreements for midstream facilities commonly allocate responsibility for their abandonment among the owners. For example, pursuant to the Petroleum Joint Venture Association (PJVA) Construction, Ownership and Operation Agreement: 1999 Model Operating Procedure (COO), if the operator is required by the operating committee or by law to salvage, clean, and restore the site of a facility, the proceeds and costs of salvaging, decommissioning, abandonment, reclamation, and disposition of any portion of the facility are shared according to the proportionate ownership of the applicable functional unit. ${ }^{161}$ Other forms of construction, ownership, and operating agreements commonly allocate the abandonment and remediation liability among the co-owners in a similar manner.

Commercial agreements increasingly provide for the funding and processes to complete abandonment and remediation at the end of the life of facilities. For example, the PJVA COO contemplates the establishment of an environmental restoration trust fund for clean-up and restoration. This fund is established by contributions from the owners. Each owner's proportionate share of the funds is to be transferred to the assignee upon any disposition. The owners remain liable (through the joint account) and receive credit for any deficiency or excess in the environmental restoration trust fund following clean-up and restoration of the facilities.

Similarly, COO agreements for pipeline, plant, and other facilities, which do not follow the PJVA COO, often contemplate abandonment or "sinking funds" whereby the owners accumulate funds for the ultimate abandonment and remediation of the midstream facilities at the end of their projected life. ${ }^{162}$ Setting up abandonment funds requires the parties to

The authors would like to extend their gratitude to Peter Bryan, a partner in the corporate commercial group with Borden Ladner Gervais LLP, who contributed his experience in drafting various oil and gas agreements to this portion of the article.

In addition to the owners, regulators, and users of midstream facilities, other stakeholders are interested in ensuring the appropriate allocation of liability for abandonment, and the proper assurances of funding. For example, right of way and other surface agreements commonly protect landowners from liabilities, damages, costs, and claims arising from abandonment of pipelines and other midstream facilities. Lenders to the midstream facility owners may include covenants in credit facilities requiring the owner to maintain abandonment and reclamation funds, prevent any other creditors from exercising any remedies against the fund, and to expressly permit the lender, or a receiver or trustee, to use the fund for the intended abandonment and reclamation purposes in the event the lender exercises its rights. Petroleum Joint Venture Association, Construction, Ownership and Operation Agreement: 1999 Model Operating Procedure, cl 1004.

162 Liquefied natural gas (LNG) facility development agreements and pipeline and processing facility coownership agreements increasingly include provision for abandonment funds from the outset of the project. 
address methods of charging the owners for contributions and the manner of interim investment, protection, ultimate use, audit, reporting, and disclosure of such funds.

In addition, or as an alternative to commercial arrangements among co-owners, owners sometimes arrange for Environmental Costs to be passed on to the facility users. Through tolls or surcharges, the costs of the liability are allocated according to use rather than ownership. ${ }^{163}$ This approach is consistent with the "cost-based/user-pay" principle, which provides that users of facilities should bear financial responsibility for costs caused by use of the facilities. ${ }^{164}$ This cost-based/user-pay principle may be complicated if the owner has not collected the fund from the inception of the facilities. Current users may resist a collection methodology that recovers for liabilities that accrue before or will accrue after their use of the facilities. Recovery methodologies will likely need to account differently for expansions, extensions, and retirement of components that occurred prior to ultimate abandonment. Finally, users and owners may differ on which party bears the risk of over- or under-funding.

\section{Claims Against Co-OWNers Under COMMON LAW PROPERTY PRINCIPLES}

Common law property principles may offer a backstop to determine liability of current coowners for Environmental Costs where legislation or a contract does not govern. Owners incurring costs on behalf of other joint owners may be able to claim against co-owners pursuant to the principles of tenants-in-common ownership or possibly bailment.

In a tenancy-in-common, ${ }^{165}$ each party is liable for capital expenditures, including repairs, and current expenses in proportion with their ownership share, unless the paying of the obligation can otherwise be explained. ${ }^{166}$ Therefore if one tenant pays the full amounts owing, they may have a claim for proportional reimbursement from the other tenants. ${ }^{167}$

An owner may also seek to recover Environmental Costs through bailment. A bailment is a temporary transfer of chattels where the bailor gives its goods to the bailee with the expectation that those goods will be returned in either their original form or altered form once the bailment period has lapsed. ${ }^{168}$ A bailment relationship may be created expressly by contract, or through the voluntary taking into custody of goods which are the property of another. ${ }^{169}$ Where petroleum substances are extracted, they become chattels which can cause environmental problems during storage or transportation. Where a bailee incurs costs related

LNG throughput agreements, pipeline transportation agreements, and gas processing facility agreements have increasingly provided for recovery of abandonment costs from customers.

For regulated facilities, the facility owner will generally be required to seek regulatory approval for the initial abandonment cost estimate, approval of a trust fund to hold abandonment costs, and a collection mechanism methodology. This process introduces additional issues which are outside the scope of this article.

Unless a sufficient intention to the contrary appears on the face of the conveying instrument, there is a presumption that where an interest in land is conveyed to two or more persons, such persons take as tenants-in-common and not as joint tenants: see Law of Property Act, RSA 2000, c L-7, s 8. Bruce Ziff, Principles of Property Law, 4th ed (Toronto: Thomson Carswell, 2006) at 327.

Ziff, ibid at 327-30. However, this may require a partition action. See Rascal Trucking Ltd v Nishi, 2011 BCCA 348, 21 BCLR (5th) 330.

Punch v Savoy’s Jewellers Ltd (1986), 54 OR (2d) 383 (CA) [Punch]; Ziff, ibid at 296-97.

Punch, ibid; Trident Construction Ltd v Capital Crane Ltd (1987), 64 Nfld \& PEIR 300 (SC Trial Div). 
to the storage or conduct of the bailment, the bailee can usually recover costs from the bailor. ${ }^{170}$ In the right case, this could include Environmental Costs.

\section{Claims Against CO-OWNERS In TORT}

The only practical tort claim that will likely arise between current co-owners is a claim by non-operators against operators for mismanagement of oil and gas assets to support a nonoperator's refusal to pay for Environmental Costs. Such claims will likely face significant hurdles given the trend in the industry to protect the operator from liability beyond its own proportionate ownership share. For example, the CAPL Procedure has always had provisions that limit the operator's liability and provide for operator indemnification. These provisions have been subject to considerable judicial scrutiny and amendment over time. ${ }^{171}$ With potential exceptions in the earlier forms of the Procedure, and provided these clauses are enforced by a court, an operator will not be held liable for other co-owners' shares of Environmental Costs unless it acts with gross negligence or wilful misconduct. ${ }^{172}$

\section{Private Recovery Against Former OWNers}

Historically, the Canadian oil and gas industry has followed the caveat emptor principal by which vendors attempt to pass risks associated with oil and gas assets, including Environmental Costs, down the chain of title through conveyances, assignments, novations, industry agreements, and contractual indemnities. While this strategy will likely be effective in many cases, there are several possible methods by which current owners may seek to share Environmental Costs with former owners, particularly where the problem giving rise to the costs arose or was continued while the former owner held an interest in the property.

\section{StATUtORy REMEDiES AND CAUSES OF ACTION AGAINST FORMER OWNERS}

Some of the statutory regimes discussed above are broad enough to allow a current owner to seek recovery of Environmental Costs from former owners through statutory causes of action or administrative remedies. For example, subject to certain statutory due diligence defences, former owners could be caught by statutory causes of action where they were a

Dorico Investments Ltd v Weyerhaeuser Canada Ltd, 1999 ABQB 561, 249 AR 53; Norman Palmer, Palmer on Bailment, 3d ed (London: Sweet \& Maxwell, Thomson Reuters, 2009) at 503-11, 754-55. 2007 CAPL Operating Procedure, supra note 140, cls 4.01, 4.02, 4.04; 1990 CAPL Operating Procedure, supra note 140, cls 401-402; 1981 CAPL Operating Procedure, supra note 143, cls 401-402; Mobil Oil Canada Ltd v Beta Well Service Ltd (1974), 2 AR 186 (SC (AD)); Erehwon Exploration Ltd $v$ Northstar Energy Corp (1993), 147 AR 1 (QB); Morrison Petroleums Ltd v Phoenix Canada Oil Co (1997), 198 AR 81 (QB); Adeco Exploration Co v Hunt Oil Co of Canada, Inc, 2008 ABCA 214, 437 AR 33 at paras $40-41,44$.

1721990 CAPL Operating Procedure, ibid, cl 402; 2007 CAPL Operating Procedure, ibid, cls 4.02(b), 1.01 (definition of "Gross Negligence or Wilful Misconduct"). 
“responsible person," ${ }^{173}$ breached a statutory duty, ${ }^{174}$ committed an offence, ${ }^{175}$ or were responsible for a discharge ${ }^{176}$ and caused the current owners damage.

In Alberta, a person who has incurred suspension, abandonment, or reclamation costs can apply to the AER to determine and allocate those costs. ${ }^{177}$ While the AER's jurisdiction is limited to allocating costs to existing licensees or working interest participants, in certain circumstances it can deem former licensees or former working interest participants to be existing licensees or working interest participants. ${ }^{178}$ It is also arguable that the costs of containing and cleaning a substance that has escaped from a pipeline could be ordered to be paid by a former operator or licensee of a pipeline, if the AER is of the view that the person "could be" responsible for the pipeline. ${ }^{179}$

\section{POTENTIAL CONTRACTUAL Liability OF FORMER OWNERS}

Current owners of oil and gas assets have a very limited ability to claim in contract against former owners for Environmental Costs. One potential avenue involves the consideration of whether a former owner might continue to be liable to subsequent owners under contracts dealing with the management of assets, even after the former owner has conveyed its interest in those assets to someone else.

At common law, parties are free to assign contractual benefits to a third party but not the corresponding burdens. ${ }^{180}$ This is subject to the exception that a party may assign all of its rights and obligations under a contract with the consent of the original contracting parties and the party receiving the assignment. Where the burdens are assigned to a third party with the consent of all, the original contract is generally said to have undergone a novation. Whether an agreement is assigned or novated could impact responsibility for Environmental Costs.

"A novation is a trilateral agreement by which an existing contract is extinguished and a new contract brought into being in its place." 181 The test to determine whether novation has occurred is threefold: (1) the new debtor must assume the complete liability; (2) the creditor must accept the new debtor as principal debtor and not merely as an agent or guarantor; and (3) the creditor must accept the new contract in full satisfaction and substitution for the old

BC EMA, supra note 82, s 47(5). The definition of "responsible person” is broad and expressly includes “a previous owner or operator of the site.” See Aldred v Colbeck, 2010 BCSC 57, 4 BCLR (5th) 364 [Aldred]; Gehring, supra note 130; Workshop Holdings Ltd v CAE Machinery Ltd, 2005 BCSC 631, 40 BCLR (4th) 382; No 158 Seabright Holdings Ltd v Imperial Oil Ltd, 2003 BCCA 57, 12 BCLR (4th) 226.

EPEA, supra note 9, s 219; BC OGAA, supra note 76, s 90.

Sask EMPA, supra note 78, s 15 . There are certain statutory defences available and limitation periods which apply to such claims. See also COGOA, supra note 62, s 26.

OGCA, supra note 4, s 30(2).

See e.g. OGCA, ibid, s 31 which allows the AER, if certain tests are met, to deem a former working interest participant in a well or facility to be a current working interest participant where the successor working interest participant fails to pay its proportionate share of suspension, abandonment, or reclamation costs. Similarly, section 31.1 allows the AER to deem a transferor of a licence for a large facility to be deemed the licensee. It is not clear whether this provision would allow the AER to go more than one step back in the chain. Pipeline Act, supra note 4, ss 36(1), (3).

National Trust Co v Mead, [1990] 2 SCR 410 at 426 [National Trust].

National Trust, ibid at 427. HG Beale, ed, Chitty on Contracts, 30th ed, vol 1 (London, UK: Thomson Reuters, 2008) at 1367. 
contract. ${ }^{182}$ Although novation may be implied from the course of conduct of the parties, it is not easily established in the absence of an express agreement. ${ }^{183}$ Some courts have held that "the terms of the contract itself can accomplish substitution of a contracting party without creating a new contract." 184 The consent of all parties is the most important difference between the concepts of assignment and novation. ${ }^{185}$

If a novation occurs, the third party (or creditor) may no longer look to the original party if the obligations under the substituted contract are not subsequently fulfilled. ${ }^{186}$ Therefore, where there has been a novation, there can be no realistic contractual claim by current owners against the former owner under the novated agreement. However, where there has only been an assignment, partial assignment, or a partial novation, ${ }^{187}$ the result is less clear. There is very little judicial guidance addressing this issue. ${ }^{188}$ In those instances, it is conceivable that a current owner may look to a former owner as continuing to be bound by the contract, particularly where the former owner's assignee is insolvent or otherwise refuses to pay. Whether such a claim is viable will depend on the specific facts and contractual arrangements between the parties. ${ }^{189}$

In the Canadian oil and gas industry, industry participants have largely agreed to standardize the assignment and novation process when interests in oil and gas assets are conveyed. Through the use of an "Industry Agreement” entered into by hundreds of oil and gas industry participants ${ }^{190}$ and its direct incorporation into agreements, ${ }^{191}$ the 1993 CAPL Assignment Procedure ${ }^{192}$ applies to the assignment and novation procedure for the vast majority of oil and gas agreements relating to real property interests in oil and natural gas and related substances. ${ }^{193}$

The Assignment Procedure creates a clear, formal process for the assignment of interests through the use of a specific form of "Notice of Assignment." The assignment is effective against third parties to the contract on the "Binding Date"194 if all of the limitations and prohibitions under the agreement are satisfied or waived, and the Notice of Assignment was

Polson v Wulffsohn (1890), 2 BCR 39 (SC), cited in National Trust, ibid.

National Trust, ibid. See also Canadian Forest Products Ltd v Powell Machinery Ltd, [1993], BCJ No 563 (QL) (SC); Lyatsky Geoscience Research and Consulting Ltd v Geocan Energy Inc, 2009 ABPC 392, [2009] AJ No 1441 (QL); Herold v British American Oil Co (1954), 12 WWR (NS) 333 (Alta SC). Weyerhaeuser Co $v$ Hayes Forest Services Ltd, 2008 BCCA 69, 78 BCLR (4th) 236 at para 28. Edmonton (City) v TransAlta Energy Marketing Corp, 2009 ABQB 709, 476 AR 136 at paras 38-41. Beale, supra note 181 at 1367.

National Trust, supra note 180 at 427.

While counterintuitive to the effect of novation, some Courts have held that an agreement may be only partially novated. See Bartolic v Canada Safeway Ltd (1998), 50 BCLR (3d) 338 (SC), citing Bank of British Columbia v Firm Holdings Ltd (1984), 57 BCLR 1 (CA).

In Talisman, supra note 123, the Court found that novation of an agreement for the management of an asset does not, of itself, constitute the conveyance of the asset to the new party.

See e.g. Monarch Construction Ltd v Axidata Inc (2007), 27 CELR (3d) 258 (Ont Sup Ct J) [Monarch] (where an attempt by a prior owner of a business to rely on a novation to avoid environmental liability failed).

CAPL, "Industry Agreement to Replace Assignment and Novation Agreements, September 1, 1993," online: CAPL < www.landman.ca/search.php?q=industry +agreement+1993> ["Industry Agreement”] See e.g. 2007 CAPL Operating Procedure, supra note 140.

1993 CAPL Assignment Procedure (Calgary: CAPL, 1993) [Assignment Procedure].

"Industry Agreement," supra note 190, cl 1.01(b).

Meaning the first day of the second calendar month following the month in which the Notice of Assignment is served in accordance with Article IV. See Assignment Procedure, supra note 192, cl 1.01(g). 
appropriately served. ${ }^{195}$ Although the Assignment Procedure refers to a "Binding Date,” as it relates to liabilities to the other parties to the contract, there is a critical distinction between the effect of the Assignment Procedure and a common law novation. Under the Assignment Procedure, the assignor expressly remains liable for obligations and liabilities which arose or accrued prior to the transfer date. ${ }^{196}$ Further, the assignee is only entitled to the benefits and bound by all obligations related to the assigned interest on or after the transfer date. ${ }^{197}$ Neither the other parties to the contract nor the assignee release the assignor from any obligation or liability which had arisen or accrued prior to the transfer date. ${ }^{198}$

As a result of the effect of the Assignment Procedure, other parties to the contract, including current working interest owners, could possibly attempt to recover Environmental Costs from former owners. This claim would be fairly straightforward for Environmental Costs that had been actually incurred prior to the transfer date. A more difficult question is whether the limited nature of the Assignment Procedure would permit a contractual claim against former owners for Environmental Costs incurred after the transfer date, but which relate to environmental contamination or other issues that arose or existed prior to the transfer date. The language of the Assignment Procedure could possibly accommodate this argument given its use of the words "arisen or accrued" to modify the obligations that the assignor is not released from by the other parties to the contract as of the transfer date. Whether that would then allow a current owner to charge current costs to a former owner would depend on the terms of the underlying agreement. For example, while the CAPL Operating Procedure seems clearly to provide that the operator can only charge costs to the current working interest owners, ${ }^{199}$ one can imagine arguments based on the Assignment Procedure to say that former owners remain liable for costs which relate to matters that arose prior to the transfer date.

\section{NEGLIGENCE ${ }^{200}$}

Current owners may consider a negligence claim against former owners or operators who caused or contributed to issues involving Environmental Costs. Current owners would need to establish that the former owners and operators owed a duty of care to future owners and operators. This might be complicated by the fact that the loss could be construed as "pure economic loss," which is generally not compensable unless the claim falls within a set of five established categories where pure economic loss has been awarded. ${ }^{201}$ If the matter does not fall within these categories, then the court will engage in an analysis of whether a new category should be recognized in accordance with the test set out in Anns v. London Borough

Ibid, cl 2.05 .

The "Transfer Date" is the effective date of the transfer of the Assigned Interest, as specified in the Notice of Assignment: ibid, cl 1.01(j).

Ibid, cl 3.01(c).

Ibid, cls 3.01(e), (f).

2007 CAPL Operating Procedure, supra note 140, cl 5.02;1990 CAPL Operating Procedure, supra note 140 at cl 502, "Joint Operator," cl 101(r).

Negligence and negligent misrepresentation in the context of a conveyance transaction is dealt with later in this article.

Design Services Ltd v Canada, 2008 SCC 22, [2008] 1 SCR 737 at para 31; Martel Building Ltd v R, 2000 SCC 60, [2000] 2 SCR 860 at para 38 [Martel]. These categories are generally described as: (1) the independent liability of statutory public authorities; (2) negligent misrepresentation; (3) negligent performance of a service; (4) negligent supply of shoddy goods or structures; and (5) relational economic loss. 
of Merton Council (the Anns Test). ${ }^{202}$ In the context of claiming damages for Environmental Costs against former owners in the oil and gas industry, the two most potentially relevant claims are the duty to warn and a new category. ${ }^{203}$

The duty to warn is usually based on the negligent supply of shoddy products or building structures, ${ }^{204}$ and depends on whether the harm was foreseeable and the relationship between the parties was sufficiently proximate. ${ }^{205}$ Arguably, in the oil and gas context the risk of harm as a result of environmental liabilities will be foreseeable, and the real issue will depend upon whether the relationship between the parties "was sufficiently proximate to justify the potential imposition of liability." ${ }^{206}$ The application of the duty to warn to a case of contaminated or defective real property, or oil and gas interests, is uncertain and would have to be applied by analogy. There is some potentially supportive authority that operates as an exception to the caveat emptor rule whereby vendors of real property owe a positive duty to warn purchasers of certain types of defects. ${ }^{207}$ It remains to be seen whether this line of authority could be extended to hold a former owner liable to current owners outside the specific title chain or more than one link down the chain. A potentially significant hurdle in the oil and gas industry context is that in most cases current owners of oil and gas interests will know, or ought to know, of any defects through their own due diligence process, or will have a general knowledge of the risks associated with oil and gas operations. It may therefore be difficult to establish that a former owner owes a duty to warn subsequent owners about something all industry participants know, or should know. ${ }^{208}$

Further, even if a court finds that a former owner of an oil and gas interest owes a duty to warn subsequent owners, the duty might only apply to dangerous defects. While some jurisdictions have expanded recovery of economic loss in negligence for non-dangerous defects, in Canada it remains at best uncertain. ${ }^{209}$ Whether or not an environmental problem

This analysis involves an assessment of the two-part test set out in Anns v London Borough of Merton, [1977] 2 All ER 492 at 498 (HL), namely: (1) is there "a sufficient relationship of proximity or neighbourhood" to justify imposition of a duty and, if so, (2) are there policy considerations which ought to negative or limit the scope of the duty, the class of persons to whom it is owed, or the damages to which breach may give rise?

Negligent misrepresentation will likely only be relevant as a potential claim if it is brought by a purchaser against a vendor. This is discussed in more detail below. Winnipeg Condominium Corporation No 36 v Bird Construction Co, [1995] 1 SCR 85 [Winnipeg Condo]; Rivtow Marine Ltd v Washington Iron Works, [1974] SCR 1189 [Rivtow Marine]; Bow Valley Husky (Bermuda) Ltd v Saint John Shipbuilding Ltd, [1997] 3 SCR 1210. The elements of this cause of action require the claimant to prove: (1) a legal duty of care was owed by a defendant to the plaintiff, specifically with respect to the subject matter; (2) the defendant had a duty to warn the plaintiff and was negligent in meeting this duty; and (3) the failure to warn caused damage to the plaintiff: Canadian Natural Resources Ltd v Arcelormittal Tubular Products Roman SA, 2013 ABQB 439, 558 AR 361. Childs v Desormeaux, 2006 SCC 18, [2006] 1 SCR 643 at para 12.

Boehner (Doug) Trucking \& Excavating Ltd v United Gulf Developments Ltd, 2007 NSCA 92, 258 NSR (2d) 41 at paras $39-40$.

Duty to warn of danger: Rivtow Marine, supra note 204; Eaton v Moore, [1951] SCR 470; Winnipeg Condo, supra, note 204. Duty to warn if unfit for human habitation: McGrath v MacLean (1979), 22 OR (2d) 784 (CA) [McGrath]; McCluskie v Reynolds (1998), 65 BCLR (3d) 191 (SC).

Deshane v Deere \& Co (1993), 15 OR (3d) 225385 (CA); Thomson v Cosgrove, [1998] BCJ No 789 (SC) (QL); Dura-Lite Heat Transfer Products Ltd v Wasteco Environmental Services Ltd, 2008 ABQB 494, 453 AR 362.

Winnipeg Condo, supra note 204 at para 42. There are examples of cases where courts have refused to strike a pleading as disclosing no cause of action on the basis that the claim was related to a nondangerous defect. See e.g. Hughes $v$ Sunbeam Corp (Canada) Ltd (2002), 61 OR (3d) 433 (CA), leave to appeal to SCC refused, 29440 (22 May 2003).denied. However, even these cases seem to involve products that were not dangerous themselves, but rely on the fact that the defective product could be dangerous. Further, some appellate courts have confirmed that the duty to warn only exists in the case of dangerous defects. See e.g. Blacklaws v 470433 Alberta Ltd, 2000 ABCA 175, 261 AR 28 at para 62. 
faced in the oil and gas industry would be considered "dangerous" would depend on the nature of the problem. In many instances, Environmental Costs do not relate to dangerous situations but rather to routine end-of-life abandonment or reclamation.

Some courts have addressed whether a new category of claim should be recognized in the context of Environmental Costs. In 66295 Manitoba Ltd. v. Imperial Oil, ${ }^{210}$ the Court assessed whether a claim in negligence by a current landowner could be maintained against former owners in respect of environmental contamination. The Court held that the first stage of the Anns Test was met:

it is clear that ... one can justify the claim being made against the former owner of property who pumps a non-natural substance onto, or places it into, his land and who sells the land and, through negligence on his part, leaves land that is contaminated with petroleum products to the extent that physical injury, injury to property and damage to the environment will be caused. ${ }^{211}$

Based on several factors, including concerns over indeterminate liability, the need for stability and finality in commercial dealings, and a reluctance to have a former owner in effect provide a subsequent owner with insurance to cover the subsequent owner's failure to make proper investigations before acquiring the property, the Court held that there were policy considerations which negated the duty of care. ${ }^{212}$ This case, and its policy reasons for preventing a claim against former owners, might very well apply to Environmental Costs in the oil and gas context. However, there is some authority which has held or implied that a duty of care can exist between former owners and current owners in relation to environmental matters. ${ }^{213}$ Until more appellate courts or the Supreme Court of Canada address this question directly, it remains a possibility that a current owner could recover in negligence against former owners of the property.

A negligence claim might face other hurdles, including contractual limitations, statutory limitations, ${ }^{214}$ contributory negligence, ${ }^{215}$ and causation issues. The lapse of time following

66295 Manitoba Ltd v Imperial Oil Ltd, 2002 MBQB 145, 165 Man R (2d) 29 [Manitoba].

Ibid at para 38 .

Ibid.

See e.g. McGeek Enterprises Ltd v Shell Canada Ltd (1991), 6 OR (3d) 216 (Gen Div), where the Court seems to have implicitly held that the former owner of lands upon which a gas station was operated can owe a duty to a subsequent owner two links down the chain, but the Court dismissed the claim because the defendant did not breach the standard of care in the circumstances. See also Heighington $v$ The Queen (1987), 60 OR (2d) 641 (H Ct J), aff'd (1989), 69 OR (2d) 484 (CA), where the Crown was held to be negligent for failing to reasonably remove radioactive soil where it was foreseeable that the health of future occupants of the land could be endangered. See also Davis v Grand (2003), 67 OR (3d) 520 (CA) [Davis], where the Court held that when a person creates a foreseeable danger to others in his or her property, the fact that the property is transferred to another person is not, in and of itself, a reason why the transferor should immediately be relieved of liability for damages. See also Giant Tiger Stores Ltd v 697781 Ontario Ltd, [1995] OJ No 3893 (Gen Div) (QL) [Giant Tiger].

Alberta: 10 years, Limitations Act, RSA 2000, c L-12, s 3(1)(b); British Columbia: 15 years, Limitation Act, SBC 2012, c 13, s 21(1); Saskatchewan: 15 years, The Limitations Act, SS 2004, c L-16.1, s 7(1); Manitoba: 30 years, The Limitation of Actions Act, CCSM c L150, s 7(5); Northwest Territories: 30 years, Limitation of Actions Act, RSNWT 1988, c L-8, s 45(2).

Negligence Act, RSBC 1996, c 333; Contributory Negligence Act, RSA 2000, c C-27; The Contributory Negligence Act, RSS 1978, c C-31; The Tortfeasors and Contributory Negligence Act, CCSM c T90; Heller v Martens, 2002 ABCA 122, 303 AR 84; MacDonald (Litigation Guardian of) v Goertz, 2009 BCCA 358, 96 BCLR (4th) 236; Indian Head Credit Union Ltd v A Hosie \& Co Ltd, [1994] 4 WWR 674, (Sask CA); Investors Group Trust Co v Gordon (1998), 131 Man R (2d) 243 (CA). 
ownership transfer may mean that at some point in time it cannot be said either that there is a relationship of proximity, or that the former owner's negligence caused the loss. ${ }^{216}$

\section{NUISANCE}

The Supreme Court of Canada has recently confirmed the two-part test for a nuisance claim: the interference with the owner's use or enjoyment of land must be both substantial and unreasonable. ${ }^{217}$ Nuisance is commonly thought of as a claim by one landowner against another. However, in the context of contaminated land cases, it has been noted that while there are no Canadian cases on point, there is no reason in principle why a former owner causing contamination might not be liable in nuisance to the current owner if the elements of the claim are otherwise made out. ${ }^{218}$ It is conceivable that this could apply not only to the party that caused the contamination, but to subsequent owners who continue it. ${ }^{219}$

While theoretically possible, it is unclear whether a claim against former owners in nuisance for Environmental Costs is an easy fit. A current owner would have to establish that the former owner's past conduct creates a substantial and unreasonable interference with the current owner's continued use of the lands or interests. Scenarios may very well arise where this is arguable, or even persuasive. However, where infrastructure has reached its end of life, or was operated reasonably and in accordance with prevailing good oilfield practices, it seems unlikely that the earlier use is a substantial or unreasonable interference with the current owner's continued use and enjoyment of the property.

\section{Claims Arising out of CONVEyance Transactions}

In the oil and gas industry, claims arising out of conveyance transactions may be influenced heavily by the doctrine of caveat emptor. Under this doctrine, there is a common law presumption that absent contractual protections providing otherwise, a purchaser of real property acquires it “as is.” ${ }^{220}$ Canadian courts have recognized the continuing vitality of the rule of caveat emptor with respect to the purchase and sale of land, and have endorsed the principle as a matter of public policy. Purchasers seeking protection concerning the fitness or quality of land should openly negotiate specific protections as a matter of contract. In cases involving written contracts, caveat emptor "provides a background common law assumption against which the written contract works."221

\footnotetext{
$216 \quad$ Davis, supra note 213, citing Giant Tiger, supra note 213.

217 Antrim Truck Centre Ltd v Ontario (Transportation), 2013 SCC 13, [2013] 1 SCR 594; Anderson v Amoco Canada Oil and Gas, 1998 ABQB 620, 225 AR 277.

218 David Estrin, Business Guide to Environmental Law (Toronto: Carswell, 1992) at 1-48.14 to 1-50, citing Masters v London Borough of Brent, [1978] 2 All ER 664 (QB). See also Almel Inc v Sunoco Inc, [1997] OJ No 3118 (QL) (Gen Div).

219 Estrin, ibid at 1-50.

220 There are several exceptions to the application of caveat emptor, some of which are discussed in more detail below.

221 Motkoski Holdings Ltd v Yellowhead (County), 2010 ABCA 72, 474 AR 367 at para 112 [Motkoski
} Holdings]. 


\section{a. Contract}

Whether a purchaser has a claim against a vendor will involve a contract-specific analysis to determine where the risk for Environmental Costs will fall. ${ }^{222}$ Many oil and gas industry participants have their own preferred forms of purchase and sale agreements. Moreover, the 2000 CAPL Property Transfer Procedure ${ }^{223}$ has not gained widespread use. The general practice in the Canadian oil and gas industry in asset purchase and sale agreements is to attempt to shift the risk for Environmental Costs to the purchaser through various provisions consistent with the caveat emptor principle, ${ }^{224}$ including: (1) clauses which provide that assets are acquired on an "as is" basis; (2) clauses which provide for significant due diligence processes and confirmation from purchasers that they have conducted their own due diligence; (3) clauses which provide that the vendor makes no, or very limited, representations or warranties regarding the assets; (4) clauses by which the purchaser acknowledges that it does not rely on any representations or information from the vendor; (5) entire agreement clauses; (6) limitation of liability clauses; and (7) indemnities by the purchaser in favour of the vendor in relation to environmental costs or problems. ${ }^{225}$

While in most cases clear contractual provisions will prevail, in appropriate circumstances purchasers may have several ways to attempt to establish vendor liability. For example, as noted above, purchasers may argue that the "Assets" conveyed did not include the assets which give rise to the Environmental Costs, thereby avoiding liability and the application of contractual indemnities in favour of the vendor. ${ }^{226}$ Further, a purchaser may argue that: there has been a common, ${ }^{227}$ mutual, ${ }^{228}$ or unilateral mistake ${ }^{229}$ supporting damages or rectification; ${ }^{230}$ that the vendor is estopped through promissory estoppel, ${ }^{231}$ estoppel by

Motkoski Holdings, ibid, at para 69.

CAPL, 2000 CAPL Property Transfer Procedure [Property Transfer Procedure]. While not used much in practice, its provisions provide insight into some of the key types of clauses that will come into play in Environmental Costs cases. See e.g. clauses 6.02, 6.05, 6.05A, 13.03-13.04.

See e.g. Antorisa Investments Ltd v 172965 Canada Ltd (2006), 82 OR (3d) 437 (Sup Ct J) [Antorisa]. See e.g. Anadarko, supra note 123; Talisman, supra note 123; Neste Chemicals Canada Inc v Reichhold Ltd (2005), 16 CELR (3d) 227 (Ont Sup Ct J).

Indemnities typically only apply to the "Assets" sold or matters "pertaining" to the Assets sold. "Pertains" requires a relationship of dependence of some substance between the property and the business; in effect the excluded asset to which the Environmental Costs relate must be an operational asset. See Talisman, ibid; Anadarko, ibid.

Ghitter (Ron) Property Consultants Ltd v Beaver Lumber Co, 2003 ABCA 221, 330 AR 353 at para 12 [Ghitter]. In the oil and gas context, it would be a rare circumstance where a common mistake relevant to Environmental Costs would be so fundamental as to upset a contract, or could practically be avoided given the difficulty or undesirability of unwinding the entire transaction.

Ghitter, ibid. In this situation, the purchaser may challenge that the parties ever reached agreement to convey the assets in question. However, it will likely be an unusual case where a mutual mistake related to Environmental Costs would be so fundamental as to void a transaction.

Ghitter, ibid. In certain circumstances a unilateral mistake can justify rectification of an agreement or damages. See Performance Industries Ltd v Sylvan Lake Golf \& Tennis Club Ltd, 2002 SCC 19, [2002] 1 SCR 678 at para 31 [Performance Industries]. Again, while unilateral mistake should not often be relevant to a dispute relating to Environmental Costs in the oil and gas industry, it should be kept in mind, as allegations that vendors engaged in fraudulent conduct or conduct "equivalent to fraud" could arise.

Rectification is available where the parties had a common continuing intention and agreement on the terms of their contract, but in error wrote them down incorrectly. See Barrett v Krebs (1995), 164 AR 218 at paras 29-38 (QB), aff'd (1996), 181 AR 132 (CA); Dynamex Canada Inc v Miller (1998), 161 Nfld \& PEIR 97 at paras 16-30 (CA); Ship MF Whelan v Pointe Anne Quarries Ltd (1921), 63 SCR 109 at 10; Hart v Boutilier (1916), 56 DLR 620 (SCC); Augdome Corporation Ltd v Gray, [1975] 2 SCR 354; Concord Pacific Group Inc v Temple Insurance Co, 2010 BCCA 275, 5 BCLR (5th) 23 at paras 31-36.

Maracle v Travellers Indemnity Co of Canada, [1991] 2 SCR 50. 
representation of fact, ${ }^{232}$ or estoppel by convention ${ }^{233}$ from taking the position that the purchaser is responsible for Environmental Costs; or that there are implied terms or covenants in the agreement, or collateral warranties outside the contract. ${ }^{234}$ Many of these arguments may fail on the terms of the agreement, or will apply only in rare circumstances. A detailed review of each of these arguments is beyond the scope of this article.

b. Tort

There is no general duty of care, or duty of disclosure, owed between parties to precontractual negotiations. ${ }^{235}$ However, in some circumstances courts will impose tort liability on parties for pre-contractual conduct. A vendor may be liable if: (1) it engages in fraudulent misrepresentation or deceit through the making of false statements which it knew were false or were made recklessly as to their truth or falsehood; ${ }^{236}(2)$ in the absence of exclusion, "no representation," or entire agreement clauses, if it negligently makes untrue, inaccurate, or misleading statements; ${ }^{237}$ (3) if it takes positive steps to conceal the truth coupled with an intention to withhold knowledge from the purchaser; ${ }^{238}$ (4) if it remains silent in the face of an obvious misapprehension by the purchaser, ${ }^{239}$ (5) if its silence renders a representation already made inaccurate; ${ }^{240}$ (6) if it brings a particular subject matter up in negotiations, or responds to a direct question posed by the purchaser, and then fails to provide all of the material facts relevant to the assertion, because "partial information is misleading information"; 241 or (7) if it fails to speak up when it subsequently discovers an earlier statement is false. ${ }^{242}$ A purchaser must also prove that the conduct related to something material, which actually induced the purchaser to enter into the contract. ${ }^{243}$ Further, where there are "no representations" or entire agreement clauses, purchasers may have to elevate

TDL Petroleums Inc v Montreal Trust Co, 2002 SKCA 91, 223 Sask R 276.

See Amalgamated Investment \& Property Co Ltd v Texas Commerce International Bank Ltd, [1981] 3 All ER 577 (CA); Ryan v Moore, 2005 SCC 38, [2005] 2 SCR 53 [Ryan]; Michael A Marion \& Layne N Thiessen, "The Doctrine of Estoppel by Convention in Canada" (2011) Annual Review of Civil Litigation 139. In Monarch, supra note 189, a former owner of a business was unsuccessful in relying on estoppel to avoid liability for Environmental Costs.

See e.g. Holtby's Design Service Inc v Campbell Chevrolet Oldsmobile Inc (2002), 46 CELR (NS) 192 (Ont Sup Ct J) [Holtby's Design].

Martel, supra note 201; Xerex Exploration Ltd v Petro-Canada, 2005 ABCA 224, 367 AR 201 at para 56 [Xerex Exploration]; Opron Construction Co v Alberta (1994), 151 AR 241 (QB) [Opron Construction]; Motkoski Holdings, supra note 221 at para 60; Ryan, supra note 233, at paras 76-78.

Stack $v$ Hildebrand, 2010 ABCA 108, 477 AR 359 at para 13 [Stack]; Motkoski Holdings, ibid at para 58.

Stack, ibid at para 12; Strand v Emerging Equities Inc, 2007 ABQB 24, 423 AR 226 [Emerging Equities]. See also Talisman, supra note 123; Aldred, supra note 173.

Xerex Exploration, supra note 235. In the case of a defect in real property, this is equated to a representation that the defect did not exist, and is fraudulent. See Motkoski Holdings, supra note 221. Motkoski Holdings, ibid at para 64; Performance Industries, supra note 229.

Xerex Exploration, supra note 235 at para 56.

Emerging Equities, supra note 237 at paras 56-57; Opron Construction, supra note 235 at para 518; Xerex Exploration, ibid; Temple v Thomas, 2006 ABQB 316, 418 AR 337 [Temple]; Alevizos v Nirula, 2003 MBCA 148, 180 Man R (2d) 186; Lerke v Brear (1990), 112 AR 1 (QB) [Lerke]. Xerex Exploration, ibid at para 57; Opron Construction, ibid at para 522.

Radhakrishnan v University of Calgary Faculty Association, 2002 ABCA 182, 312 AR 143 at para 64. This may often be a difficult hurdle to overcome in a case involving liability for Environmental Costs, depending on the size of the transaction and the quantum or nature of the environmental issues. The focus of the parties (or at least the purchaser) will typically be on acquiring or selling operational, productive, or prospective oil and gas assets. The existence of possible Environmental Costs, while clearly factored into the economics, will often not be something that would cause a purchaser to walk away from a transaction. See e.g. Antorisa, supra note 224. 
their claim and allege that the vendor acted fraudulently to avoid contractual disclaimers. ${ }^{244}$ Intentional suppression or obfuscation of environmental issues by a vendor may very well expose the vendor to liability for Environmental Costs.

\section{c. Exceptions to Caveat Emptor}

Where caveat emptor applies, it is often said to be subject to several exceptions, including fraud. ${ }^{245}$ These exceptions appear to be covered under other contractual or tort principles as well, but the fraud exception warrants further discussion. Over time, courts have refined this exception to require that the vendor knowingly concealed a known, latent (not patent) defect that could not be discovered on reasonable inspection by the purchaser, ${ }^{246}$ and which the purchaser would not have accepted had it been disclosed. In effect, this appears to be a different way of expressing the elements of the tort of deceit.

In the context of an oil and gas transaction where environmental issues leading to Environmental Costs are not disclosed, this raises a number of questions. ${ }^{247}$ Firstly, is the alleged defect even a defect at all? It has been held that if the defect does not prevent the use for which the property was acquired, then it is not a defect for the purposes of the exception. ${ }^{248}$ Many alleged defects relating to environmental problems in the context of an oil and gas transaction would not meet this definition because they would not prevent the use of the property for further development, processing, or transportation of oil and gas resources. Secondly, is the alleged defect latent or patent in the sense that it should be discoverable by the purchaser? Whereas "patent defects are those that can be discovered by conducting a reasonable inspection and making reasonable inquiries about the property,"249 latent defects are "some fault ... that is not readily apparent to an ordinary purchaser during a routine inspection.”" ${ }^{250}$ Generally, there is a high onus on a purchaser to conduct a reasonable inspection of the property and discover patent defects. ${ }^{251}$ This questions the level of inspection required by the purchaser, and the authorities on this point are not clear. ${ }^{252} \mathrm{An}$ oil and gas industry participant that has been given extensive due diligence rights, including

Motkoski Holdings, supra note 221. The decision to allege fraudulent conduct can be difficult because it elevates the reputational and other risks for both sides. For example, unsubstantiated allegations of fraud can result in elevated cost consequences at trial: Malamas $v$ Crerar Property Corp, 2012 ONSC 1197, [2012] OJ No 849 (QL); Botan v St Amand, 2012 ABQB 260, 538 AR 307.

245 Di Cenzo Construction Co Ltd v Glassco (1978), 21 OR (2d) 186 (CA); Alessio v Jovica, [1973] AJ No 205 (QL) (SC (AD)); Nesbitt v Redican (1923), 54 OLR 154 (AD); Temple, supra note 241 at para 39. There are four general exceptions to the doctrine of caveat emptor that appear to be recognized: (1) fraud; (2) a mutual mistake resulting in a total failure of consideration or a deficiency in the land conveyed amounting to error in substantialibus; (3) a contractual condition; or (4) a warranty collateral to the contract which survives closing.

246 Tony's Broadloom \& Floor Covering Ltd v NCM Canada Inc (1995), 22 OR (3d) 244 (Gen Div) [Tony's Broadloom]; Ceolaro v York Humber Ltd (1994), 53 CPR (3d) 276 at 347 (Ont (Gen Div)): "The only time caveat emptor is not applicable is where there is a latent defect”; Palmer $v$ Van Keulen, 2005 ABQB 239, 375 AR 341 (active concealment of a latent defect); Temple, supra note 239.

Property Transfer Procedure, supra note 223, incorporates additional provisions in recognition of the doctrine of caveat emptor. First, the Transferor cannot mislead the Transferee about the condition of the Assets through fraud or suppression or active non-disclosure of a material latent defect. Secondly, the Transferor has a duty to disclose latent dangerous conditions to the Transferee if the defect would not have been readily apparent through the Transferee's due diligence efforts. Tony's Broadloom, supra note 246.

Cardwell v Perthen, 2007 BCCA 313, 68 BCLR (4th) 117 at para 25 [Cardwell].

Temple, supra note 241 at para 52, citing Swayze v Robertson (2001), 39 RPR (3d) 114 (Ont Sup Ct J). Cardwell, supra note 249; Holtby's Design, supra note 234; Antorisa, supra note 224.

Cardwell, ibid; Tony’s Broadloom, supra note 246; Temple, supra note 241; Gibb v Sprague, 2008 ABQB 298, 447 AR 8 [Gibb]; Franks v Golunski, 2005 ABPC 109, [2005] AJ No 464 (QL). 
the right to visit well sites or facilities, might have difficulty establishing that a defect was latent. Thirdly, what nature of defect is required? Again, the law is unclear. Some cases suggest that the defect must be "major," ${ }^{253}$ and others suggest that it must be dangerous to property or persons. ${ }^{254}$ Many environmental problems might not be major in proportion to a particular oil and gas transaction. Some defects pose a danger to property or persons; many others do not. Fourthly, what level of knowledge and conduct are required by the vendor to invoke the exception? ${ }^{255}$ Again, the cases vary. Some require that the vendor have actual knowledge of the defect, ${ }^{256}$ while others suggest that it is sufficient if the vendor is reckless as to the knowledge of the defect. ${ }^{257}$ What is clear is that if a vendor fraudulently conceals a defect, neither caveat emptor nor contractual disclaimers will apply, and a purchaser may have a remedy.

\section{Contractual Allocation OR Exclusion OF Liabilty}

Normally, courts recognize that a properly worded exclusion clause should be enforced according to its true meaning. ${ }^{258}$ However, in some cases purchasers may challenge the enforceability of the clauses used by the oil and gas industry to protect vendors. The Supreme Court of Canada in Tercon $^{259}$ set out a three-part analytical framework for challenging such clauses. Firstly, as a matter of interpretation, does the exclusion clause apply to the circumstances established in evidence? Exclusion clauses are interpreted strictly against those they protect. Secondly, if the clause applies, was the clause unconscionable at the time the contract was made, "as might arise from situations of unequal bargaining power between the parties”? ${ }^{260}$ Thirdly, if the clause is held to be valid and applicable, should the court nevertheless refuse to enforce it because of the existence of an overriding public policy, proof of which lies on the party seeking to avoid enforcement of the clause, that outweighs the very strong public interest in the enforcement of contracts.

Exclusion clauses have been found ineffective in limiting a vendor's liability in the face of fraudulent misrepresentations. ${ }^{261}$ In the oil and gas context, in Plas-Tex ${ }^{262}$ the Alberta Court of Appeal determined that a supplier who knew that its plastic resin for pipeline

Lerke, supra note 241.

Sevidal v Chopra (1987), 64 OR (2d) 169 (H Ct J) (suggests defect requires immediate danger or harm); Caleb v Potts, [1986] OJ No 1125 (QL) (H Ct J); Godin v Jenovac (1993), 35 RPR (2d) 288 (Ont (Gen Div)) (no duty to disclose unless there is a health or safety risk). But see Beaulne v Ellenor, 2000 ABPC 117, 274 AR 286 at para 31: "I take as a general proposition that a vendor is under a positive duty to disclose those matters that affect the physical state of the property which would render or create a difference in substance between what the purchaser understood was being purchased and in fact what was purchased.”

This question engages an analysis very similar to when a purchaser is obligated to make full disclosure under the law of express misrepresentation or misrepresentation by silence or by partial disclosure. McGrath, supra note 207. See also: Home Exchange (Alberta) Ltd v Goodyear Canada Inc, $2007 \mathrm{ABQB}$ 371, 418 AR 1.

Temple, supra note 241 at para 45 . See also Gibb, supra note 252 at para 27.

Hunter Engineering Co v Syncrude Canada Ltd, [1989] 1 SCR 426 [Hunter Engineering]; Tercon, supra note 124.

Tercon, ibid.

Hunter Engineering, supra note 258 at para 59; Tercon, ibid. It has been stated that “....unconscionability should be used sparingly to avoid a limitation of liability clause, but should be applied in such a way as to preclude a party to a contract from engaging in unconscionable conduct, secure in the knowledge that no liability can be imposed because of an exemption clause": see Martel v Mohr, 2011 SKQB 161, 370 Sask R 104 at paras 83-92, citing Plas-Tex Canada Ltd v Dow Chemical of Canada Ltd, 2004 ABCA 309, 357 AR 139 [Plas-Tex].

Motkoski Holdings, supra note 221.

Plas-Tex, supra note 260. 
manufacturing was defective and would cause pipelines to fail could not avoid liability by not disclosing this fact to its customer and then protecting itself with an exclusion clause. The Supreme Court has stated that "what was demonstrated in Plas-Tex was that the defendant ... was so contemptuous of its contractual obligation and reckless as to the consequences of the breach as to forfeit the assistance of the court. The public policy that favours freedom of contract was outweighed by the public policy that seeks to curb its abuse."263

Although the Tercon framework related to exclusion clauses, the commentary by the Supreme Court seems to address the more general jurisdiction of the courts to override contractual obligations. ${ }^{264}$ There seems no reason why that framework might not also apply, with modification, to any contractual provision designed to protect vendors or purchasers relating to environmental issues arising in oil and gas transactions. ${ }^{265}$ This is particularly so when one considers the public policy favouring the protection of the environment and the polluter pays principle. ${ }^{266}$

\section{CONCLUSION}

The public statutory and regulatory framework is designed to ensure the environment is protected and, if necessary, to allocate the costs of reclamation, remediation, and abandonment. Current or former owners who find themselves liable pursuant to the statutory and regulatory scheme are then left with a complex and uncertain private framework to attempt to recover or share those costs. As oil and gas industry participants grapple with the consequences of aging infrastructure, it is expected that the industry, legislatures, administrative tribunals, and courts will have the opportunity in the future to further clarify who will pay for the resultant Environmental Costs. Policy in Canadian Contract Law” (2007) Annual Review of Civil Litigation 1.

See e.g. Freedom Cycle Inc v Canadian Kawasaki Motors Inc, 2006 NSSC 347, 249 NSR (2d) 268. The manufacturer was liable in negligence for damages resulting from a gasoline spill attributed to faulty installation of a motorcycle gas tank despite an exclusionary clause. The Court determined that the limiting conditions could not be read so broadly as to save Kawaski harmless from the resulting damage that may occur if a defect resulted in foreseeable environmental damage. 